\title{
Lipoprotein(a) - Structure, Epidemiology, Function and Diagnostics of a Cardiovascular Risk Marker
}

\author{
R. Siekmeier ${ }^{1, *}$, H. Scharnagl ${ }^{2}$, G.M. Kostner ${ }^{3}$, T. Grammer ${ }^{4}$, T. Stojakovic ${ }^{2}$ and W. März ${ }^{2,4}$
}

\author{
${ }^{I}$ Bundesinstitut für Arzneimittel und Medizinprodukte (BfArM), Kurt-Georg-Kiesinger-Allee 3, Bonn, Deutschland; \\ ${ }^{2}$ Klinisches Institut für Medizinische und Chemische Labordiagnostik, Medizinische Universität Graz, Graz, Österreich; \\ ${ }^{3}$ Institut für Medizinische Biochemie und Medizinische Molekularbiologie, Medizinische Universität Graz, Graz, Öster- \\ reich and ${ }^{4}$ Synlab - Medizinisches Versorgungszentrum für Labordiagnostik Heidelberg, Eppelheim, Deutschland, \\ Germany
}

\begin{abstract}
Decades after its first description by Berg 1963 lipoprotein(a) (Lp(a)) is an established risk marker of cardiovascular diseases which is independent from other risk markers. The main difference of $\mathrm{Lp}(\mathrm{a})$ compared to LDL is the apo(a) residue which is covalently bound to apoB. Apo(a) is a glycoprotein which underlies a large genetic polymorphism. The latter is caused by a variation of the kringle-IV-type-2 repeats of the protein which is characterized by a large structural homology to plasminogen. The $\mathrm{Lp}$ (a) plasma concentration in the population is highly skewed and determined to more than $90 \%$ by genetic factors. In healthy subjects the $\mathrm{Lp}(\mathrm{a})$-concentration is correlated to its synthesis and not to its metabolism. Plasma concentrations of Lp(a) are affected by different diseases (e.g. diseases of liver and kidney), hormonal factors (e.g. sexual steroids, glucocorticoids, thyroid hormones), individual and environmental factors (e.g. age, cigarette smoking) as well as pharmaceuticals (e.g. derivatives of nicotinic acid) and therapeutic procedures (lipid apheresis). However, even though a large number of studies on $\mathrm{Lp}(\mathrm{a})$ were performed up to now many details of its physiological function and regulation of plasma concentration are not yet understood. In addition, studies showed contradictory results because there were large differences of the included patients, use of not sufficiently validated tests as well as analysis of frozen samples. Aim of our review was to describe function and physiological regulation of $\mathrm{Lp}(\mathrm{a})$ as well as factors influencing its plasma concentration.
\end{abstract}

Key Words: Lipoprotein (a), plasma lipoproteins, atherosclerosis, coronary heart disease.

\section{INTRODUCTION}

Lipoprotein (a) $(\mathrm{Lp}(\mathrm{a}))$, for the first time described in 1963 by Berg belongs to the lipoproteins with the strongest atherogenic effect $[1,2]$. Its importance for the development of various atherosclerotic vasculopathies (coronary heart disease, ischemic stroke, peripheral vasculopathy, abdominal aneurysm), however, was recognised only considerably later [3-6]. With regard to its structure, lipoprotein(a) is a low density lipoprotein (LDL), to whose apolipoprotein B (apoB) another protein, i.e. apolipoprotein(a) (apo(a)) is covalently bound by a disulfide-bridge [7]. The physiological function of $L p(a)$ is unknown to date, since test persons with very low or not detectable $\mathrm{Lp}$ (a) plasma concentrations do not present a specific phenotype. Vice versa, however, numerous studies have shown that elevated $L p(a)$ plasma concentrations are associated with an increased risk of atherosclerotic diseases (coronary heart disease, peripheral arterial occlusive disease, cerebral stroke) [6, 8-33]. Apo(a) synthesis is performed in the liver, probably followed by extracellular assembly to the apoB moiety of the LDL [34]. The biological half life of $\mathrm{Lp}(\mathrm{a})$ is known from kinetic investigations and exceeds the

*Address correspondence to this author at the Bundesinstitut für Arzneimittel und Medizinprodukte, (BfArM), Kurt-Georg-Kiesinger-Allee 3, 53175 Bonn, Germany; Tel: 0049/228-207-5360; Fax: 0049/228-207-5300;

E-mail: r.siekmeier@bfarm.de half life of LDL [35, 36]. However, only little is known about the details of $L p(a)$ catabolism. It is assumed that the kidney has a specific function in $\operatorname{Lp}$ (a) catabolism, since the nephrotic syndrome and terminal kidney failure are associated with an elevation of the $\mathrm{Lp}(\mathrm{a})$ plasma concentration [37, 38]. One consequence of the poor knowledge of the metabolic paths of $\operatorname{Lp}(a)$ is the fact that so far pharmaceutical science has failed to develop drugs that are able to reduce elevated $L p(a)$ plasma concentrations to the desired extent.

\section{STRUCTURAL CHARACTERISTICS OF Lp(a)}

$\mathrm{Lp}$ (a) is a complex particle which mainly consists of a LDL molecule, to whose apoB the glycoprotein apo(a) is covalently bound. To a small extent, however, apo(a) has also been detected bound to triglyceride-rich lipoproteins (Very Low Density Lipoproteins; VLDL). Corresponding to the structural similarity to LDL, both particles are very similar to each other with regard to their composition (values in weight percentage; values of LDL in brackets): protein: 30 $\%(22.5 \%)$, cholesteryl ester: $35.5 \%$ (43\%), free cholesterol: $8.5 \%$ (11\%), phospholipids: $19.5 \%$ (19.5\%), triglycerides: $2 \%(3 \%)$ and carbohydrates $4.5 \%(1 \%)[35,39]$. Apo(a) shows a distinct structural homology to plasminogen, whose gene is also located on chromosome $6[40,41]$. The kringle repeats of apo(a) present a particularly characteristic 
structure, which have a high similarity to kringle IV (K IV) of plasminogen. Additionally, apo(a) contains a kringle $\mathrm{V}$ structure of plasminogen and a protease domain, which cannot be activated, as opposed to the one of plasminogen [2, $40,41]$. At least 30 genetically determined apo(a) isoforms were identified in man, which are the basis for the marked heterogeneity of the molecular size. The individual apo(a) isoforms differ by the number of K IV units in the molecule, i.e. corresponding to a molecular weight of approximately $12.5 \mathrm{kDa}$ per K IV unit [2, 40, 42, 43]. The smallest apo(a) isoform consists of one protease domain, one $\mathrm{K} \mathrm{V}$ unit and $11 \mathrm{~K}$ IV units, while the apo(a) isoform of the highest molecular weight has $52 \mathrm{~K} \mathrm{IV}$ units. Between the individual K IV units there are highly glycosylated connection units [2].

\section{Lp(a) METABOLISM}

Apo(a) is synthesised predominantly, if not exclusively, in the liver. After its synthesis, apo(a) binds with high affinity to apoB on LDL. The binding is then probably completed on the hepato-cellular surface via a disulfide-bridge of the Cys4326 of apoB and the only free cysteine group in K IV type 9 (Cys4057) of apo(a) [2, 44]. The synthesis of $L p(a)$ is thus a two-step process [45]. In a first step, which can be competitively inhibited by lysine analogues, the free sulfhydryl groups of apo(a) and apoB are brought close together. The binding of apo(a) then occurs near the domain of apo B which binds to the LDL receptor, resulting in a reduced affinity of $\mathrm{Lp}(\mathrm{a})$ to the LDL receptor. Particles that show a reduced affinity to the LDL receptor, such as particles containing apoB-48 and VLDL are not able to form stable complexes with apo(a) [2]. Thus the largest part of apo(a) is present as apo(a) bound to LDL. Only a small, quantitatively variable part of apo(a) remains as free apo(a) and probably plays an important role in the metabolism of $\operatorname{Lp}(\mathrm{a})[2,46]$. Investigations into the metabolism have shown that the synthesis rate of $\mathrm{Lp}(\mathrm{a})$ is strongly related to its plasma concentration and therefore depends on the apo(a) isoform that determines plasma concentration, while the catabolism rate is only of little significance [36].

The metabolic path of the synthesised Lp(a) is to a large extent unknown. Due to the similarity of the composition of LDL and $\mathrm{Lp}(\mathrm{a})$ it was first assumed that $\mathrm{Lp}(\mathrm{a})$, like other lipoproteins containing apoB, is degraded via the LDL receptor. Thus it could be shown in in vitro experiments that the binding of $\mathrm{Lp}(\mathrm{a})$ to fibroblasts could be competitively inhibited by addition of LDL, but compared to LDL, Lp(a) only had a small affinity to the LDL receptor. Animal experiments (rat, rabbit, hedgehog) showed that the liver plays an important role in $\mathrm{Lp}$ (a) metabolism - followed by the kidney and the spleen [35]. On the other hand, kinetic investigations performed in man, which demonstrated a longer plasma half life for $\mathrm{Lp}$ (a) compared to LDL, allowed the conclusion that the LDL receptor practically has no function in the metabolism of $\mathrm{Lp}(\mathrm{a})$. The fractional catabolic rates for LDL and $\mathrm{Lp}(\mathrm{a})$ are 0.38 and 0.26 , respectively, in normal persons and are practically the same as for homozygous patients with a defect of the LDL receptor (0.205 and 0.210 , respectively) $[35,36]$. This phenomenon was the reason that other metabolic paths are now being discussed for $\mathrm{Lp}(\mathrm{a})$. Apo(a) obviously separates from apoB in the blood and as a consequence it comes to a subsequent fragmentation into degradation products of different molecular weight induced by metalloproteinases $[2,47]$. As could be shown in experiments in transgenic mice, the resulting degradation products are removed from circulation by different organs and tissues, and only a very small part of them (less than $1 \%$ of apo(a)) is excreted with the urine [2, 47, 48]. Other, receptordependent metabolic paths are assumed for the $\mathrm{Lp}(\mathrm{a})$ metabolism. Among them are the LDL receptor related protein, megalin, the VLDL receptor and the galactose-specific asialoglycoprotein receptor (ASGPR) [2, 49].

\section{GENETICS AND PLASMA CONCENTRATION}

The plasma concentration of $\mathrm{Lp}(\mathrm{a})$ is not evenly distributed in the population, but is highly skewed with regard to frequency, whereby the concentrations among different individuals may differ by a factor of 1000 [35, 50, 51]. Correspondingly the normal values of the Caucasian population show a median of approximately $8 \mathrm{mg} / \mathrm{dL}$ to $10 \mathrm{mg} / \mathrm{dL}$, while the mean values are at an approximate level of 16 $\mathrm{mg} / \mathrm{dL}$ to $18 \mathrm{mg} / \mathrm{dL}[35,52]$. The concentrations in Black Africans are twice as high as in Caucasians, while the plasma concentrations of Asian individuals are distinctly below that value, although the underlying causes are not finally clarified [2]. The concentrations are determined by genetic factors and are considered subject to only low variations during lifetime $[35,53]$. But despite that a continuous rise of $\mathrm{Lp}$ (a) plasma concentrations [2] is found mainly in the first weeks after birth and in the course of the later decades in life. There is a distinct inverse correlation between the respective molecular weight of the $L p(a)$ and of the number of kringle-IV-domains in the apo(a) part of the lipoprotein particle and the individual plasma concentrations, respectively. Thus individuals with a high $\mathrm{Lp}$ (a) molecular weight show a low plasma concentration, while individuals with a low $\mathrm{Lp}(\mathrm{a})$ molecular weight present high plasma concentrations $[34,54,55]$. The reason for this is the fact that apo(a) isoforms with a high molecular weight are stronger bound and degraded in the rough endoplasmic reticulum, in the Golgi apparatus and in proteasomes than apo(a) isoforms with a low molecular weight $[56,57]$. A total of $50 \%$ of the genetic variation of the plasma concentration is determined by the respective number of kringle-IV-domains, while approximately $45 \%$ of the genetic variation of the plasma concentrations are attributable to polymorphisms and mutations of the promoter region (pentanucleotide repeat, TTTTA), to the coding regions (+93 $\mathrm{C} / \mathrm{T}$ polymorphism) and to other variations of the apo(a) gene $[2,35]$.

\section{PHYSIOLOGICAL FUNCTIONS OF Lp(a)}

Based on the results of the initial investigations by Berg [1], the opinion prevailed for many years, that individuals without detectable $\mathrm{Lp}$ (a) plasma concentrations (so-called Lp(a)-negative individuals) did not have any defect. Due to the increasing sensitivity of the analytical procedures used in the detection it could be shown that the plasma concentrations of these individuals were only below $25 \mathrm{mg} / \mathrm{dL}$. Later investigations in individuals with $\mathrm{Lp}$ (a) plasma concentrations of $<0.5 \mathrm{mg} / \mathrm{dL}$ showed a disproportionately high excretion of apo(a) fragments in the urine of these individuals [2]. Now further investigation results allow the conclusion that apart from its significance as an important agent in the development of atherosclerosis, Lp(a) has even more physiological functions, e.g. in wound healing, angiogenesis and 
hemostasis [2, 40, 58]. In the context of pleiotropic actions, however, the favourable action mechanisms are opposed by pathogenetic mechanisms, whereby the importance of $\mathrm{Lp}$ (a) in atherogenesis should be particularly mentioned (Table 1) $[14,16,17,40,58]$.

Table 1. Pathogenetic Mechanisms by which Elevated Lp(a) Plasma Concentrations Lead to an Accelerated Atherothrombosis [14,16,17,40,58] (Modified According to [17])

\begin{tabular}{l} 
Easy oxidisability of Lp(a) and formation of highly atherogenic \\
complexes with LDL in the vessel wall \\
Increase of oxidation rate, uptake and retention of LDL \\
Enhancement of lipid uptake by macrophages \\
Competitive inhibition of plasminogen during the binding to cellular \\
receptors and protein binding sites \\
Decreased thrombin formation and inhibition of fibrinolysis \\
\hline Inhibition of t-PA and increased formation of PAI-1 \\
\hline Inactivation of tissue factor pathway inhibitors \\
\hline Increase of thrombin synthesis \\
\hline Facilitation of thrombus formation at sites of tissue lesions \\
\hline Increase of proliferation and migration of smooth vascular muscle cells \\
\hline Inhibition of transforming growth factor $\beta$ \\
\hline Increased expression of intercellular adhesion molecules \\
\hline Inhibition of the formation of collateral vessels \\
\hline
\end{tabular}

\section{Lp(a) IN WOUND HEALING}

Individual investigations indicate a possible favourable role of $\mathrm{Lp}(\mathrm{a})$ in wound healing [39, 58]. After tissue lesions $\mathrm{Lp}$ (a) plasma concentrations may increase as a consequence of an acute phase reaction $[2,39,58]$, then it comes to an accumulation of $\operatorname{Lp}(\mathrm{a})$ at the lesion and subsequently to a proliferation of smooth vascular muscle cells and endothelial cells and to a release of cholesterol into the tissue [58-60]. This led to the theory that a few million years ago, when plasma cholesterol concentrations were assumed to be much lower, $L p(a)$ could have been a substantial source for the supply of tissues with cholesterol which was to be used in tissue regeneration and repair. This would have been an evolutionary advantage, which later transformed into a risk factor due to altered circumstances $[39,58]$.

\section{Lp(a) IN ANGIOGENESIS}

$\mathrm{Lp}(\mathrm{a})$ is also important for the process of angiogenesis and the sprouting of new vessels. This is based on the fact that angiogenesis starts with the remodelling of matrix proteins and the activation of matrix metalloproteinases (MMP). The latter ones are usually synthesised as inactive zymogens and require activation by proteases, this is also accomplished by plasminogen. The marked structural homology of $\mathrm{Lp}(\mathrm{a})$ to plasminogen, with a simultaneous lack of protease activity, may indicate that $\mathrm{Lp}(\mathrm{a})$ has an antiangiogenetic effect
[2]. Accordingly, an antiangiogenetic effect of $L p(a)$ and apo(a) and its fragments excreted with the urine could be demonstrated in transgenic mice and in vitro [61, 62]. In the in vitro assay apo(a) did not have any effect on the accumulation of plasminogen activator-inhibitor I (PAI-I) and only little influence on the activation of urokinase, which indicates that for the inhibition of angiogenesis in vivo further influences have to be of importance [2, 62]. In another animal experiment it could be shown that apo(a) leads to an inhibition of the angiogenesis-dependent tumour growth in the colon of nude mice [63].

Finally it should be stated that elevated $\mathrm{Lp}$ (a) plasma concentrations are found in individuals over eighty years and in tumour patients, as opposed to healthy individuals. These increases indicate that individuals with higher $\mathrm{Lp}$ (a) concentrations, provided they do not develop atherosclerosis, may have a certain protection against tumour diseases or that $\mathrm{Lp}$ (a) may have a certain function in tumour defence [2, 39]. Likewise, the plasminogen fragments have an antiantiangiogenetic effect due to their homologous structure [39]. In summary it can be said, however, that the possible relationships between an antiangiogenetic effect of $\mathrm{Lp}(\mathrm{a})$ and a possible protection against tumour formation are only insufficiently known and require extensive further experimental investigation.

\section{Lp(a) IN HEMOSTASIS}

Due to the marked structural homology between the apo(a) part and plasminogen, which both belong to the socalled plasminogen group [41], a relationship between the coagulation system and Lp(a) was assumed quite early [64]. $\mathrm{Lp}(\mathrm{a})$ is able to competitively inhibit the binding of plasminogen to fibrinogen and fibrin, and to inhibit the fibrindependent activation of plasminogen to plasmin via the tissue plasminogen activator [64-66], whereby apo(a) isoforms of low molecular weight have a higher affinity to fibrin than apo(a) isoforms of higher molecular weight [65]. Like other compounds containing sulfhydryl groups, homocysteine enhances the binding of $\mathrm{Lp}(\mathrm{a})$ to fibrin [67]. During fibrinolysis, physiological importance of which lies in the dissolution of fibrin deposits and in the restoration of an injured vascular endothelium [68], the binding of plasminogen to lysine residues results in plasmin activation and subsequently in the enhancement of the following fibrinolytic processes [69-74]. $\mathrm{Lp}$ (a) binding also involves lysine [65] with the consequence, that due to the lack of catalytic activity it comes to hypofibrinolysis and, due to the LDL-component of the $\mathrm{Lp}(\mathrm{a})$, to an accumulation of cholesterol $[2,40,41,58,65$, 75-77]. Moreover, Lp(a) stimulates the synthesis of plasminogen activator-inhibitor I (PAI-I) in endothelial cells or of PAI-II in monocytes [2, 78]. The thus induced decrease of plasmin activity is not only important for the fibrinolytic system, since plasmin is also required for the activation of transforming growth factor- $\beta 1$ (TGF- $\beta 1$ ) which plays an important role in the proliferation and migration of the smooth vascular muscle cells within the atherosclerotic process [79]. Another relationship, which also favours the formation of thromboses, between $\mathrm{Lp}(\mathrm{a})$ and the fibrinolytic system is found in its property, to bind to the Tissue Factor Pathway Inhibitor (TFPI), a regulator of the tissue factor (TF)-mediated coagulation, expressed in activated monocytes, endothelial cells and thrombocytes [58, 80-84], and to 
subsequently inactivate this factor [85]. But in addition to the mentioned prothrombotic properties $\mathrm{Lp}$ (a) also has antithrombotic properties. Thus $\mathrm{Lp}(\mathrm{a})$ binds with high affinity and specificity to the platelet activating factor acetylhydrolase. This does not only result in the inhibition of PAF, one of the strongest trigger factors of thrombocyte aggregation, but also in the hydrolysis of the short-chain phospholipids that develop during the process of lipid oxidation [2, 86-88]. Additionally, Lp(a) also leads to the inhibition of the collagen-induced thrombocyte aggregation and to the inhibition of serotonin and thromboxan secretion $[2,89]$. In summary it shows that via various mechanisms Lp(a) possesses both prothrombotic and antithrombotic properties, which may be an explanation for the contradictory trial results achieved in different patient cohorts, since the properties of $\mathrm{Lp}(\mathrm{a})$ find different expression [2].

Several studies demonstrate a role of $\mathrm{Lp}(\mathrm{a})$ as an important risk marker, partly independent of other risk markers, for the occurrence of an acute coronary syndrome and spontaneous, partly recurring, ischemic strokes and of venous thromboses and thromboembolism in children and adults [58, 90-96], while other investigations did not establish any relationship between the occurrence of thrombotic events or thromboembolism and the existence of an elevated $\mathrm{Lp}$ (a) plasma concentration [97-99]. Moreover, elevated Lp(a) plasma concentrations were measured in a number of studies performed in patients with early-stage or terminal kidney diseases and autoimmune diseases (antiphospholipid syndrome, systemic sclerosis, chronic thromboembolic pulmonary hypertension, rheumatoid arthritis and systemic lupus erythematosus), which fact supports the involvement of $\mathrm{Lp}(\mathrm{a})$ in the increased occurrence of thromboembolic events [100-109].

\section{Lp(a) IN ATHEROSCLEROSIS}

The importance of $\mathrm{Lp}(\mathrm{a})$ in the formation and progression of atherosclerotic vascular diseases could be demonstrated in numerous animal experiments. Thus evidence was supplied that in transgenic, hyperlipidemic and $\mathrm{Lp}(\mathrm{a})$ expressing Watanabe rabbits, $\mathrm{Lp}$ (a) leads to enhanced atherosclerosis with development of calcifications [110-112]. Under the influence of $\operatorname{Lp}(\mathrm{a})$, the binding of $\mathrm{Lp}$ (a) to glycoproteins, e.g. laminin, results - via its apo(a)-part [113-115] both in an increased invasion of inflammatory cells [116, 117] and in an activation of smooth vascular muscle cells with an increased formation of alkaline phosphatase and subsequent calcifications $[111,112]$ in the vascular wall. The inhibition of TGF-1 $\beta$ activation is another mechanism via which $\mathrm{Lp}$ (a) contributes to the development of atherosclerotic vasculopathies. TGF- $1 \beta$ is subject to proteolytic activation by plasmin and its active form leads to an inhibition of the proliferation and migration of smooth muscle cells, which play a central role in the formation and progression of atherosclerotic vascular diseases [79, 118-120]. If TGF-1 $\beta$ fails to be activated, e.g. due to $\operatorname{Lp}(\mathrm{a})$ accumulation in the vascular wall, it is associated with an increased proliferation and migration of the smooth vascular muscle cells and the formation of atherosclerotic lesions [79, 118, 121, 122].

In man, $\mathrm{Lp}(\mathrm{a})$ is an important risk marker which is independent of other risk markers. Its importance, partly also under consideration of the molecular weight and other ge- netic polymorphisms, could be demonstrated by a high number of epidemiological and clinical studies investigating the formation and progression of atherosclerosis, myocardial infarction, and stroke and also by meta-analyses [6, 8-33]. The simultaneous presence of other risk markers, e.g. hypercholesterolemia, hyperfibrinogenemia or reduced HDLcholesterol, will lead to an even stronger increase of the total risk for the occurrence of cardiovascular diseases due to $\mathrm{Lp}$ (a) $[11,13,31]$. However, there are other studies that could not find evidence for the role of $L p(a)$ as a risk marker for cardiovascular diseases, e.g. the Physicians Health Study $[2,123]$. Possible causes for such negative results may be performance of analyses with samples that were stored for too long and the use of insufficiently validated test kits, but also the investigation of smaller study populations, which are subject to an increased influence of the skewed distribution of the $\mathrm{Lp}$ (a) plasma concentration in the population $(<0.1$ $\mathrm{mg} / \mathrm{dL}$ up to $>300 \mathrm{mg} / \mathrm{dL}$ ) [2].

\section{INFLUENCE OF DISEASES ON Lp(a) PLASMA CONCENTRATION}

Predominantly, the $\mathrm{Lp}$ (a) plasma concentration is considered genetically determined [35, 53]. But a number of factors may lead to an increase or decrease of the plasma concentration. In the following, some of these factors will be discussed in detail. Cholestatic liver diseases, particularly those that are characterised by high concentrations of lipoprotein $\mathrm{X}$, are associated with reduced $L p(a)$ concentrations. In these cases it is assumed that a lack of normal LDL is the cause for this phenomenon, which leads to an impairment of the assembly of LDL and apo(a) [2].

Many studies have investigated the influence of chronic kidney diseases on the concentration and metabolism of plasma lipoproteins. Elevated Lp(a) plasma concentrations were found in patients with diabetic microscopic albuminuria [17], nephrotic syndrome [17, 105, 109], nephropathy [17] and kidney failure of different etiology and stages [17, 26, 104, 105, 107, 108]. The high number of those studies shows that $\mathrm{Lp}(\mathrm{a})$ plays an important part as a risk marker for the development of cardiovascular diseases in patients with kidney diseases [17, 26, 104].

On account of the interleukin-6 (IL-6) dependent regulation of $L p(a)$ synthesis, $L p(a)$ can to a certain extent be regarded as an acute phase protein [2], with the consequence, that inflammatory stimulants may be associated with a particularly marked elevation of the $\mathrm{Lp}$ (a) plasma concentration [124, 125].

\section{HORMONAL INFLUENCE ON THE Lp(a) PLASMA CONCENTRATION}

Several hormonal factors, that are either attributable to the respective underlying diseases or to therapeutic administration, lead to alterations of the $L p(a)$ plasma concentration, which are partly opposed to the alterations of the other plasma proteins. Thus patients with disturbed thyroid function present marked alterations of the fat metabolism [2, 35, 126] if compared to euthyroid patients. Hypothyroidism is associated with an increase of $\mathrm{Lp}(\mathrm{a})$ concentrations, while vice versa, hyperthyroidism is accompanied by a decrease of Lp(a). Manifest diseases show more marked alterations than 
subclinical stages. The same applies under administration of a therapy. Thus triiodothyronine $\left(\mathrm{T}_{3}\right)$ or thyroxine $\left(\mathrm{T}_{4}\right)$ substitution results in a decrease of $\mathrm{Lp}(\mathrm{a})$ plasma concentration, while the administration of a thyroid inhibitor is associated with an increase. In both cases the therapeutic alterations are all the more marked, the more distinct the manifestations of the underlying hormonal disturbance are [2, 35, 126].

Animal experiments performed in transgenic mice showed a regulation of the apo(a) gene by sexual steroids. Testosterone leads to down-regulation [127]. While endogenous testosterone does not have a relevant effect on the $\mathrm{Lp}(\mathrm{a})$ plasma concentration [128], the supplementation of testosterone or other androgenic substances (e.g. nandronlone acetate, stanozolol, dehydroepiandrosterone) is associated with a suppression of the $\mathrm{Lp}(\mathrm{a})$ plasma concentration [128-131]. Vice versa, an orchidectomy will result in an increase of $\mathrm{Lp}$ (a) due to the low testosterone levels [130]. The administration of gonadotropin releasing hormone agonists and antagonists, which act via the inhibition of testosterone synthesis [132-135] has a similar effect. The same applies to the administration of antiandrogens, e.g. of the $5 \alpha$-reductase inhibitor finasteride, which may also result in an elevation of Lp(a) [136].

The female sexual steroids also have an influence on various parameters of the fat metabolism [137, 138]. While in premenopausal women with normal menstrual cycles, we observe no or only little alteration of $\operatorname{Lp}(a)$ [139-142], the stimulation with follicle-stimulating hormone (FSH) in the luteal phase will result in a temporary increase [140, 142]. Once the women have reached the postmenopausal stage (due to physiological, pharmacological or surgical reasons), the associated hormonal alterations also result in a distinct elevation of $L p(a)$ [143-148]. A hormone replacement therapy with estrogen as a monotherapy or in combination with progesterone leads to a decrease of $\mathrm{Lp}(\mathrm{a})$ in these patients, which is particularly marked in those women whose pretherapy $\operatorname{Lp}(\mathrm{a})$ concentrations were elevated [143, 144, 147, 148]. In postmenopausal women with breast cancer the frequently administered estrogen receptor-modifying substances such as tamoxifen and toremifene [149, 150], but not aromatase inhibitors, such as letrozole [151] also lead to a decrease of $\operatorname{Lp}(\mathrm{a})$.

The influence of a number of additional hormones on $\mathrm{Lp}$ (a) plasma concentrations is also discussed. The administration of corticotropin or its analogues (e.g. synacthene) leads to a distinct decrease of $\operatorname{Lp}(\mathrm{a})$ [2, 152-154], both in healthy individuals and in patients with terminal renal failure and hemodialysis and in patients after kidney transplantation. With regard to diabetes mellitus there exists a whole range of partly contradictory publications. Insulin does not directly influence the Lp(a) plasma concentration [35]. A comparison with healthy individuals shows that the $\mathrm{Lp}(\mathrm{a})$ in patients with type 1 diabetes mellitus show hardly any alterations, which means that an improvement of the metabolic control is not associated with an alteration of $\operatorname{Lp}(a)[2,35]$. Contrary to that patients with type 2 diabetes mellitus show more frequently an increase of $\mathrm{Lp}(\mathrm{a})$ compared to healthy individuals, which may be secondarily induced, since the patients studied excrete fewer apo(a) fragments with the urine than healthy individuals due to a concomitant limitation of the renal function $[2,155]$.

\section{INFLUENCE OF NUTRITION AND LIFE-STYLE ON Lp(a) PLASMA CONCENTRATIONS}

Many studies have investigated the influence of alcohol on the Lp(a) plasma concentration. The chronic consumption of ethanol results in a marked decrease of the $L p(a)$ concentration which is dose-dependent and has no relationship with the size polymorphism of apo(a) [2, 156, 157]. Vice versa the $L p(a)$ concentration rises again after termination or reduction of alcohol consumption [158-160]. The mechanism of action is not completely known. It is discussed that it involves insulin-like growth factor (IGF)-binding protein [2, 159].

Furthermore there are investigations that observed an influence of different nutritional styles on $\mathrm{Lp}(\mathrm{a})$ concentrations. Trans-fatty acids such as elaidic acid, which is found in deep-fried food, obviously lead to a $25 \%$ - $50 \%$ increase of $\mathrm{Lp}(\mathrm{a})$ concentration, which is particularly marked in individuals with initially elevated $\mathrm{Lp}$ (a) concentrations $[17,161$, 162]. Vice versa several studies also discuss that mono- or poly-unsaturated fatty acids or fat-modified foods may have a lowering and protective effect on $\mathrm{Lp}$ (a) plasma concentrations $[17,163-165]$.

Several studies and overviews describe decreased Lp(a) plasma concentrations in smokers as compared to nonsmokers [2, 166-168]. Vice versa such an influence could not be established in other studies that were performed partly with monozygotic twins [169-171].

Finally a possible effect of exercise on $\mathrm{Lp}$ (a) concentrations should be mentioned. While some studies could not observe an alteration of the $\mathrm{Lp}$ (a) concentration [172-174], older studies showed a slight increase without further clinical relevance $[170,175]$.

\section{THERAPEUTIC MODIFICATION OF Lp(a)}

A large number of studies investigated the influence of therapy forms on Lp(a) plasma concentrations. The administration of niacin or nicotinic acid may produce a distinct decrease of $\mathrm{Lp}(\mathrm{a})$, with simultaneous favourable influence on other parameters of the lipid metabolism. Moreover it is possible, to combine nicotinic acid with other substances, such as gemfibrozil and inhibitors of hydroxymethyl-CoAreductase (statins) [2, 176-179].

Although fibrates (to include gemfibrozil) in vitro decrease the mRNA for $L p(a)$ [180], rather controversial results have been obtained in vivo for the effect of these drugs on Lp(a) plasma concentrations [2].

Lipid apheresis is an effective method for which a number of approaches are available, but due to its invasiveness and the necessity of a frequent repetition (at least every two weeks) it is more or less regarded as ultima ratio. The procedures that are primarily developed for the removal of LDL allow a reduction of $\mathrm{Lp}$ (a) plasma concentrations by up to 80 $\%$, depending on the volume of blood or plasma that is treated [2, 181-183].

By contrast, the different statins, if administered as monotherapy, do not only fail to achieve a decrease of $\operatorname{Lp}(\mathrm{a})$, but partly may even lead to an increase. Only a small number of studies observed a decrease of $\mathrm{Lp}(\mathrm{a})$ under the administration of statins $[2,35,184-188]$. Analogously, this applies to 
substances which inhibit intestinal cholesterol absorption (e.g. resins) and which may be combined with other antilipemics, particularly with statins, to enhance the cholesterollowering effect [184-186].

Apart from these substances long established in the therapy of dyslipidemia there are other pharmaceuticals, only recently introduced into therapy and new compounds still in the phase of development [189]. Substances specifically targeting the peroxisome proliferator-activated receptor (PPAR) [189] are particularly important in this context. This group includes thiazolidindiones (e.g. pioglitazone, rosiglitazone, troglitazone). Studies in type 2 diabetics were able to show a favourable influence of these substances on the glycometabolic control and lipid metabolism, and additionally a decrease of the $\mathrm{Lp}$ (a) plasma concentrations under the therapy $[190,191]$.

Various studies investigated the influence of fatty acids, particularly fish oil, and $\omega 3$ - and $\omega 6$-fatty acids on $L p(a)$ plasma concentrations. The results obtained in these studies are altogether quite controversial and stating either an increase of $\mathrm{Lp}(\mathrm{a})$, denying any influence or even observing a decrease [2, 163, 165, 192].

Finally there are also individual studies with partly controversial results, which indicate a possible favourable influence originating from other compounds such as carnitine [2, 193-196], coenzyme $Q_{10}[197,198]$ or aspirin $[199,200]$.

\section{ANALYTICS OF Lp(a)}

A considerable number of studies investigating the cardiovascular risk factor $\mathrm{Lp}(\mathrm{a})$ shows controversial results, whereby the contradictions may be a consequence of both the study design and the analytical methods used for that purpose (Table 2) [17, 201, 202]. The following paragraphs will discuss the analytical causes for the variability.

In the past, the $\operatorname{Lp}(\mathrm{a})$ concentrations were often determined with analytical procedures that allow only a very limited comparability of the results. At present the $\mathrm{Lp}(\mathrm{a})$ value is determined by electrophoresis, electroimmunodiffusion, electroimmunoassays, radioimmunoassays, immunoradiometric assays, immunoturbidimetric assays and enzyme-linked immunoassays (ELISAs) [16, 17]. The electrophoretic methods have the advantage that they are not dependent on the polymorphism of Lp(a) [17, 203, 204]. Although larger studies could show the value of these methods, they have the disadvantage that with a specificity of $95 \%$ their sensitivity with regard to the detection of $\mathrm{Lp}$ (a) concentrations $>30 \mathrm{mg} / \mathrm{dL}$ is only $51 \%$, which limits their use in scientific investigations $[17,205]$.

The heterogeneity of apo(a) with regard to size constitutes an analytical problem in so far, as the antibodies used by most manufacturers are specific for the K IV type 2 epitope $[17,201]$. Depending on the molecular weight this results in a variable immune reactivity with overestimation of concentrations in cases of high or underrating in cases of low molecular weights of apo(a). As a consequence of a use of these antibodies studies may have had controversial results with regard to the relationship between $\mathrm{Lp}(\mathrm{a})$ and vascular diseases [17, 201].

Based on experiences from the past, the International Federation of Clinical Chemistry and Laboratory Medicine
(IFCC) developed an international reference material (IFCC SRM 2B) with a defined amount of $\operatorname{Lp}(\mathrm{a})$ and a monoclonal antibody against an epitope in K IV type 9, which occurs only once per apo(a) molecule and thus delivers results that are not dependent on the molecular weight [17, 206]. ELISAs on the basis of this reference material are independent of the apo(a) isoform and could in the future serve as gold standard for $\mathrm{Lp}(\mathrm{a})$, which is already recognised by the National Heart, Lung and Blood Institute (NHLBI) and the World Health Organization (WHO) as "First WHO/IFCC International Reagent for Lipoprotein(a) for Immunoassay". The availability of this standard would enable the manufacturers to minimise the inaccuracy and between batch variability of the antibodies and to improve the comparability of the Lp(a) assays in scientific investigations [17, 206, 207].

The additional determination of the molecular weight of apo(a) or of the isoform would further improve the risk assessment, but is not yet available in a suitable form for clinical routine use. On account of the inverse relationship between molecular weight and concentration, the exact determination of the $\mathrm{Lp}$ (a) plasma concentrations appears suitable, for the time being, to determine the individual risk [17].

Table 2. Causes for Contradictory Results in Studies Investigating $L p(a)[17,201,202]$

\begin{tabular}{|l|}
\hline Analysis \\
\hline $\begin{array}{l}\text { Different analytical methods with/without relationship to apo(a) iso- } \\
\text { forms }\end{array}$ \\
\hline Lacking standardisation of methods \\
\hline $\begin{array}{l}\text { Different degree of degradation of Lp(a) with a distinct decrease of } \\
\text { concentrations with smaller apo(a)isoforms }\end{array}$ \\
\hline $\begin{array}{l}\text { Underrating of the concentration of smaller apo(a) isoforms with simul- } \\
\text { taneous overrating of larger apo(a) isoforms }\end{array}$ \\
\hline Study cohorts and study design \\
\hline Small number of samples \\
\hline $\begin{array}{l}\text { Different age of investigated individuals and inclusion of older } \\
\text { individuals }\end{array}$ \\
\hline Different study end points \\
\hline Ethnic differences \\
\hline Different sex \\
\hline Length of follow-up period \\
\hline Stringency of exclusion criteria \\
\hline Application of different statistical methods for data evaluation \\
\hline
\end{tabular}

Finally it also has to be considered that the quality of the results obtained for $\mathrm{Lp}(\mathrm{a})$ depends to a considerable extent on the quality of the sample. In the meantime it is an established fact that the prolonged storage of plasma samples results in an enhanced degradation of the smaller Lp(a) isoforms, while larger isoforms do not degrade to such an extent, which will lead to false negative results. It is assumed that the storage of samples over several years or storage under suboptimal conditions leads to a decrease of $\mathrm{Lp}(\mathrm{a})$ con- 
centrations by $25 \%$ or up to $50 \%$ [17, 208-210]. Thus the negative results of many studies that were unable to show a relationship between $\mathrm{Lp}(\mathrm{a})$ concentration and vascular diseases, are at least partly the consequence of the analysis of frozen samples, while on the other hand those studies that analysed suitable biological material, established a distinct relationship between $\mathrm{Lp}(\mathrm{a})$ and vascular events [17, 201]. This applies all the more, since it seems that small apo(a) isoforms have a greater importance as risk markers than larger isoforms [17].

Several investigations indicate that, as opposed to other risk markers, the $\mathrm{Lp}$ (a) plasma concentration dependent risk for the occurrence of cardiovascular diseases does not rise continuously $[17,201]$. In the case of plasma concentrations above the $80^{\text {th }}$ percentile one can assume the presence of an increased individual risk [17]. The reported cut-off values, however, show considerable differences. Many studies that analysed frozen samples with methods dependent on apo(a) isoforms, described cut-off values for $\mathrm{Lp}(\mathrm{a})$ of $>30 \mathrm{mg} / \mathrm{dL}$ up to $40 \mathrm{mg} / \mathrm{dL}$. The analysis of fresh samples showed an increase of the risk already at concentrations of $>20 \mathrm{mg} / \mathrm{dL}$ in the white population. Under consideration of the ethnic differences applying to $L p(a)$, however, higher cut-off values would have to be determined for black individuals and lower ones for Asian individuals, which are at present only available to a small extent. This means that for the time being the $80^{\text {th }}$ percentile could be regarded as suitable cut-off, above which the cardiovascular risk is substantially increased [17, 201].

In most laboratories the $\mathrm{Lp}(\mathrm{a})$ assay is performed by reporting the mass. Occasionally, assays and results are expressed as $\mathrm{Lp}(\mathrm{a})$-protein or $\mathrm{Lp}(\mathrm{a})$-cholesterol. Unless further specified, the $L p(a)$ mass is usually determined. Under consideration of the composition of the particle, the statement of $20 \mathrm{mg} / \mathrm{dL} \mathrm{Lp(a)} \mathrm{corresponds} \mathrm{to} \mathrm{values} \mathrm{of} 7 \mathrm{mg} / \mathrm{dL} \mathrm{Lp}(\mathrm{a})$ protein or Lp(a)-cholesterol [17]. The NHLBI recommends to stop using data for total $\mathrm{Lp}(\mathrm{a})$, and to use nmol/L units instead, which consider the number of particles. The NHLBI also recommends performing the analysis with International Reference Material [17, 206, 207]. In white individuals, values above $75 \mathrm{nmol} / \mathrm{L}$ are regarded as a cut-off value for the presence of an increased risk [17, 207]. Methods should be applied that are not dependent on the apo(a) isoform [17, 201]. If methods are used that are not independent of the apo(a) isoform, then $\mathrm{Lp}$ (a) values $>50 \mathrm{nmol} / \mathrm{L}$ should be subjected to another analysis using a method independent of the isoform [17, 207].

\section{RECOMMENDATIONS CONCERNING THE DE- TERMINATION OF THE Lp(a) PLASMA CONCEN- TRATION}

Although the third report of the American National Cholesterol Education Program recognises the importance of the $\mathrm{Lp}$ (a) plasma concentration as cardiovascular risk marker, it does not recommend its determination within the framework of general routine analyses $[17,211]$. The determination of $\mathrm{Lp}$ (a) concentration, however, is recommended in patients with a positive familial history of a cardiovascular disease or in patients with manifest genetically determined dyslipidemia $[17,211]$. However, considering the fact that $L p(a)$ is a factor that is to a large extent independent of the remaining risk markers for atherosclerotic and thromboembolic diseases, the quantitative determination should be considered even in the other patient and risk groups listed in Table $\mathbf{3}$ [17].

Table 3. Patient- and Risk Groups where an Assay of the Lp(a) Plasma Concentration is Recommended (According to [17])

\begin{tabular}{|c|}
\hline $\begin{array}{l}\text { Individuals with a positive familial history of vascular diseases, in par- } \\
\text { ticular with premature death }\end{array}$ \\
\hline $\begin{array}{l}\text { Patients with a personal history of a premature heart disease, a stroke } \\
\text { or a peripheral vasculopathy, independent of other risk markers }\end{array}$ \\
\hline $\begin{array}{l}\text { Patients with remaining stenosis after coronary angioplasty, vascular } \\
\text { stent implantation or bypass-surgery }\end{array}$ \\
\hline Patients and individuals with so-called statin resistance \\
\hline Adopted individuals \\
\hline $\begin{array}{l}\text { Individuals with an otherwise inexplicable expression of heart disease, } \\
\text { including those patients with a rapid progression documented by } \\
\text { angiography, a complex morphology of the lesion and a total or } \\
\text { persistent occlusion of one or more coronary arteries }\end{array}$ \\
\hline Individuals with thrombus formation in the left atrium \\
\hline
\end{tabular}

In addition, it is the opinion of the authors that measurement of $\mathrm{Lp}(\mathrm{a})$ concentration is also indicated in individuals who are at an only slightly increased risk (risk for the incidence of a severe coronary event between $10 \%$ and $20 \%$ in 10 years according to the current methods for risk stratification) in which decisions for or against pharmacological interventions (e.g. treatment with antilipemics or antihypertensives) are difficult to make.

\section{REFERENCES}

[1] Berg, K. A new serum type system in man: The LP system. Acta Pathol. Scand., 1963, 59, 369-382.

[2] Kostner, K.M.; Kostner, G.M. Therapy of Hyper-Lp(a). Handb. Exp. Pharmacol., 2005, 170, 519-536.

[3] Dahlen, G.H.; Guyton, J.R.; Attar, M.; Farmer, J.A.; Kautz, J.A.; Gotto, A.M. Association of levels of lipoprotein Lp(a), plasma lipids, and other lipoproteins with coronary artery disease documented by angiography. Circulation, 1986, 74, 758-765.

[4] Jones, G.T.; van Rij, A.M.; Cole, J.; Williams, M.J.; Bateman, E.H.; Marcovina, S.M.; Deng, M.; McCormick, S.P. Plasma lipoprotein(a) indicates risk for 4 distinct forms of vascular disease. Clin. Chem., 2007, 53, 679-685.

[5] Kostner, G.M.; Avogaro, P.; Cazzolato, G.; Marth, E.; Bittolo-Bon, G.; Quinici, G.B. Lipoprotein (a) and the risk for myocardial infarction. Atherosclerosis, 1981, 38, 51-61.

[6] Terres, W.; Tatsis, E.; Pfalzer, B.; Beil, F.U.; Beisiegel, U.; Hamm, C.W. Rapid angiographic progression of coronary artery disease in patients with elevated lipoprotein(a). Circulation, 1995, 91, 948950 .

[7] Kostner, G.M.; Krempler, F. Lipoprotein(a). Curr. Opin. Lipidol., 1992, 3, 279-284.

[8] Ariyo, A.A.; Thach, C.; Tracy, R.; for the Cardiovascular Health Study Investigators. Lp(a) lipoprotein, vascular disease, and mortality in the elderly. N. Engl. J. Med., 2003, 349, 2108-2115.

[9] Bostom, A.G.; Cupples, L.A.; Jenner, J.L.; Ordovas, J.M.; Seman, L.J.; Wilson, P.W.; Schaefer, E.J.; Castelli, W.P. Elevated plasma lipoprotein(a) and coronary heart disease in men aged 55 years and younger. A prospective study. JAMA, 1996, 276, 544-548. 
[10] Budde, T.; Fechtrup, C.; Bosenberg, E.; Vielhauer, C.; Enbergs, A.; Schulte, H.; Assmann, G.; Breithardt, G. Plasma Lp(a) levels correlate with number, severity, and length-extension of coronary lesions in male patients undergoing coronary arteriography for clinically suspected coronary atherosclerosis. Arterioscler. Thromb., 1994, 14, 1730-1736.

[11] Cantin, B.; Despres, J.P.; Lamarche, B.; Moorjani, S.; Lupien, P.J.; Bogaty, P.; Bergeron, J.; Dagenais, J.R. Association of fibrinogen and lipoprotein(a) as a coronary heart disease risk factor in men (The Quebec Cardiovascular Study). Am. J. Cardiol., 2002, 89, 662-666.

[12] Christopher, R.; Kailasanatha, K.M.; Nagaraja, D.; Tripathi, M. Case-control study of serum lipoprotein(a) and apolipoproteins A-I and B in stroke in the young. Acta Neurol. Scand., 1996, 94, 127130 .

[13] Cobbaert, C.; Jukema, J.W.; Zwinderman, A.H.; Withagen, A.J.A. M.; Lindemans, J., Bruschke, A.V.G.; on behalf of the Regression Growth Evaluation Statin Study (REGRESS) Study Group. Modulation of lipoprotein(a) atherogenicity by high density lipoprotein cholesterol levels in middle-aged men with symptomatic coronary artery disease and normal to moderately elevated serum cholesterol. J. Am. Coll. Cardiol., 1997, 30, 1491-1499.

[14] Craig, W.Y.; Neveux, L.M.; Palomaki, G.E.; Cleveland, M.M.; Haddow, J.E. Lipoprotein(a) as a risk factor for ischemic heart disease: Metaanalysis of prospective studies. Clin. Chem., 1998, 44, 2301-2306.

[15] Cremer, P.; Nagel, D.; Labrot, B.; Mann, H.; Muche, R.; Elster, H.; Seidel, D. Lipoprotein $\mathrm{Lp}(\mathrm{a})$ as predictor of myocardial infarction in comparison to fibrinogen, LDL cholesterol and other risk factors: Results from the prospective Göttingen Risk Incidence and Prevalence Study (GRIPS). Eur. J. Clin. Invest., 1994, 24, 444-453.

[16] Danesh, J.; Collins, R.; Peto, R. Lipoprotein(a) and coronary heart disease. Meta-analysis of prospective studies. Circulation, 2000, 102, 1082-1085

[17] Enas, E.A.; Chacko, V.; Senthilkumar, A.; Puthumana, N.; Mohan, V. Elevated lipoprotein(a) - A genetic risk factor for premature vascular disease in people with and without standard risk factors: A review. Dis. Mon., 2006, 52, 5-50.

[18] Evans, R.W.; Shpilberg, O.; Shaten, B.J.; Ali, S.; Kamboh, M.I.; Kuller, L.H. Prospective association of lipoprotein(a) concentrations and apo(a) size with coronary heart disease among men in the Multiple Risk Factor Intervention Trial. J. Clin. Epidemiol., 2001, 54, 51-57.

[19] Fruchart, J.C.; Nierman, M.C.; Stroes, E.S.G.; Kastelein, J.J.P.; Duriez, P. New risk factors for atherosclerosis and patient risk assessment. Circulation, 2004, 109(Suppl. III), III-15-III-19.

[20] Gaw, A.; Murray, H.M.; Brown, E.A.; and the PROSPER Study Group. Plasma lipoprotein(a) [Lp(a)] concentrations and cardiovascular events in the elderly: Evidence from the prospective study of pravastatin in the elderly at risk (PROSPER). Atherosclerosis, 2005, 180, 381-388.

[21] Gazzaruso, C.; Bruno, R.; Pujia, A.; de Amici, E.; Fratino, P.; Solerte, S.B.; Garzaniti, A. Lipoprotein(a), apolipoprotein(a) polymorphism and coronary atherosclerosis severity in type 2 diabetic patients. Int. J. Cardiol., 2006, 108, 354-358,

[22] Glader, C.A.; Birgander, L.S.; Stenlund, H.; Dahlen, G.H. Is lipoprotein(a) a predictor for survival in patients with established coronary artery disease? Results from a prospective patient cohort study in northern Sweden. J. Intern. Med., 2002, 252, 27-35.

[23] Hartmann, M.; von Birgelen, C.; Mintz, G.S.; Stoel, M.G.; Eggebrecht, H.; Wieneke, H.; Fahy, M.; Neumann, T.; van der Palen, J.; Louwerenburg, H.W.; Verhorst, P.M.J.; Erbel, R. Relation between lipoprotein(a) and fibrinogen and serial intravascular ultrasound plaque progression in left main coronary arteries. J. Am. Coll. Cardiol., 2006, 48, 446-452.

[24] Hernandez, C.; Francisco, G.; Chacon, P.; Simo, R. Lipoprotein(a) as a risk factor for cardiovascular mortality in type 2 diabetic patients: A 10-year follow-up study. Diabetes Care, 2005, 28, 931933.

[25] Holmer, S.R.; Hengstenberg, C.; Kraft, H.G.; Mayer, B.; Pöll, M.; Kürzinger, S.; Fischer, M.; Löwel, H.; Klein, G.; Riegger, G.A.J.; Schunkert, H. Association of polymorphisms of the apolipoprotein(a) gene with lipoprotein(a) levels and myocardial infarction. Circulation, 2003, 107, 696-701.

[26] Kronenberg, F.; Kronenberg, M.F.; Kiechl, S.; Trenkwalder, E.; Santer, P.; Oberhollenzer, F.; Egger, G.; Utermann, G.; Willeit, J.
Role of lipoprotein(a) and apolipoprotein(a) phenotype in atherogenesis: Prospective results from the Bruneck study. Circulation, 1999, 100, 1154-1160

[27] Lippi, G.; Guidi, G. Lipoprotein(a): An emerging cardiovascular risk factor. Crit. Rev. Clin. Lab. Sci., 2003, 40, 1-42.

[28] Luc, G.; Bard, J.M.; Arveiler, D.; Ferrieres, J.; Evans, A.; Amouyel, P.; Fruchart, J.C.; Ducimetiere, P.; on behalf of the PRIME Study Group. Lipoprotein (a) as a predictor of coronary heart disease: The PRIME Study. Atherosclerosis, 2002, 163, 377384.

[29] Milionis, H.J.; Filippatos, T.D.; Loukas, T.; Bairaktari, E.T.; Tselepis, A.D.; Elisaf, M.S. Serum lipoprotein(a) levels and apolipoprotein(a) isoform size and risk for first-ever acute ischaemic nonembolic stroke in elderly individuals. Atherosclerosis, 2006, 187, 170176.

[30] Shintani, S.; Kikuchi, S.; Hamaguchi, H.; Shiigai, T. High serum lipoprotein(a) levels are an independent risk factor for cerebral infarction. Stroke, 1993; 24, 965-969.

[31] von Eckardstein, A.; Schulte, H.; Cullen, P.; Assmann, G. Lipoprotein(a) further increases the risk of coronary events in men with high global cardiovascular risk. J. Am. Coll. Cardiol., 2001, 37, 434-439.

[32] Wild, S.H.; Fortmann, S.P.; Marcovina, S.M. A prospective casecontrol study of lipoprotein(a) levels and apo(a) size and risk of coronary heart disease in Stanford Five-City Project participants. Arterioscler. Thromb. Vasc. Biol., 1997, 17, 239-245.

[33] Zorio, E.; Falco, C.; Arnau, M.A.; Espana, F.; Osa, A.; Ramon, L.A.; Castello R.; Almenar, L.; Palencia, M.A.; Estelles, A. Lipoprotein (a) in young individuals as a marker of the presence of ischemic heart disease and the severity of coronary lesions. Haematologica, 2006, $91,562-565$.

[34] White, A.L.; Lanford, R.E. Cell surface assembly of lipoprotein(a) in primary cultures of baboon hepatocytes. J. Biol. Chem., 1994, 269, 28716-28723.

[35] Kostner, G.M. Lipoprotein(a): Metabolismus und Beeinflussung des Plasmaspiegels. J. Kardiol., 2002, 9, 321-324

[36] Krempler, F.; Kostner, G.M.; Bolzano, K.; Sandhofer, F. Turnover of lipoprotein (a) in man. J. Clin. Invest, 1980, 65, 1483-1490.

[37] Kronenberg, F.; Utermann, G.; Dieplinger, H. Lipoprotein(a) in renal disease. Am. J. Kidney Dis., 1996, 27, 1-25.

[38] Thiery, J.; Ivandic, B.; Bahlmann, G.; Walli, A.K.; Seidel, D. Hyperlipoprotein(a)aemia in nephrotic syndrome. Eur. J. Clin. Invest. 1996, 26, 316-321

[39] Lippi, G.; Guidi, G. Lipoprotein(a): From ancestral benefit to modern pathogen? Q. J. Med., 2000, 93, 75-84.

[40] Leischik, R.; Dworrak, B.; Gülker, H. Lipoprotein(a): Koronare Herzerkrankung - klinische Bedeutung und Therapieoptionen. Dtsch. Med. Wochenschr., 2005, 130, 2518-2523.

[41] McLean, J.W.; Tomlinson, J.E.; Kuang, W.J.; Eaton, D.L.; Chen, E.Y.; Fless, G.M.; Scanu, A.M.; Lawn, R.M. cDNA sequence of human apolipoprotein(a) is homologous to plasminogen. Nature, 1987, 330, 132-137.

[42] Marcovina, S.M.; Zhang, S.H.; Gaur, V.P.; Albers, J.J. Identification of 34 apolipoprotein(a) isoforms: Differential expression of apolipoprotein(a) alleles between American blacks and whites. Biochem. Biophys. Res. Commun., 1993, 191, 1192-1196.

[43] Marcovina, S.M.; Koschinsky, M.L. Lipoprotein(a) concentration and apolipoprotein(a) size: A synergistic role in advanced atherosclerosis? Circulation, 1999, 100, 1151-1153.

[44] Frank, S.; Kostner, G.M. The role of apo-(a) kringle-IVs in the assembly of lipoprotein-(a). Protein Eng., 1997, 10, 291-298.

[45] Frank, S.; Durovic, S.; Kostner, G.M. Structural requirements of apo-a for the lipoprotein-a assembly. Biochem. J., 1994, 304, 27 30

[46] Gries, A.; Nimpf, J.; Nimpf, M.; Wurm, H.; Kostner, G.M. Free and apoB-associated $\mathrm{Lp}$ (a) specific protein in human serum. Clin. Chim. Acta, 1987, 164, 93-100.

[47] Frank, S.; Hrzenjak, A.; Blaschitz, A.; Dohr, G.; Kostner, G.M Role of various tissues in apo(a) fragmentation and excretion of fragments by the kidney. Eur. J. Clin. Invest., 2001, 31, 504-512.

[48] Kostner, K.M.; Maurer, G.; Huber, K.; Stefenelli, T.; Dieplinger, H.; Steyrer, E.; Kostner, G.M. Urinary excretion of apo(a) fragments. Role in apo(a) catabolism. Arterioscler. Thromb. Vasc. Biol., 1996, 16, 905-911. 
[49] Hrzenjak, A.; Frank, S.; Wo, X.; Zhou, Y.; van Berkel, T.; Kostner, G.M. Galactose-specific asialoglycoprotein receptor is involved in lipoprotein (a) catabolism. Biochem. J., 2003, 376, 765-771.

[50] Lackner, C.; Cohen, J.C.; Hobbs, H.H. Molecular definition of the extreme size polymorphism in apolipoprotein(a). Hum. Mol. Genet., 1993, 2, 933-940.

[51] Utermann, G. The mysteries of lipoprotein(a). Science, 1989, 246, 904-910

[52] Kostner, G.M.; Gries, A.; Pometta, M.; Molinari, E.; Pichler, P.; Aicher, H. Immunochemical determination of lipoprotein Lp(a): Comparison of Laurell electrophoresis and ELISA. Clin. Chim. Acta, 1990, 188, 187-192.

[53] Puckey, L.; Knight, B. Dietary and genetic interactions in the regulation of plasma lipoprotein(a). Curr. Opin. Lipidol., 1999, 10, 35-40.

[54] Kraft, H.G.; Lingenhel, A.; Pang, R.W.C.; Delport, R.; Trommsdorf, M.; Vermaak, H.; Janus E.D.; Utermann, G. Frequency distributions of apolipoprotein(a) kringle IV repeat alleles and their effects on lipoprotein(a) levels in Caucasian, Asian, and African populations: The distribution of null alleles is non-random. Eur. J. Hum. Genet., 1996, 4, 74-84.

[55] Utermann, G.; Menzel, H.J.; Kraft, H.G.; Duba H.C.; Kemmler, H.G.; Seitz, C. Lp(a) glycoprotein phenotypes. Inheritance and relation to $\mathrm{Lp}$ (a)-lipoprotein concentrations in plasma. J. Clin. Invest., 1987, 80, 458-465.

[56] White, A.L.; Hixson, J.E.; Rainwater, D.L.; Lanford, R.E. Molecular basis for "null" lipoprotein(a) phenotypes and the influence of apolipoprotein(a) size on plasma lipoprotein(a) level in the baboon. J. Biol. Chem., 1994, 269, 9060-9066.

[57] White, A.L.; Guerra, B.; Wang, J.; Lanford, R.E. Presecretory degradation of apolipoprotein [a] is mediated by the proteasome pathway. J. Lipid Res., 1999, 40, 275-286.

[58] Leischik, R.; Dworrak, B. Bedeutung für das fibrinolytische System und thromboembolische Komplikationen. Herz, 2006, 31, 144152.

[59] Pillarisetti, S.; Paka, L.; Obunike, J.C.; Berglund, L.; Goldberg, I.J. Subendothelial retention of lipoprotein (a). Evidence that reduced heparan sulfate promotes lipoprotein binding to subendothelial matrix. J. Clin. Invest., 1997, 100, 867-874

[60] Yano, Y.; Shimokawa, K.; Okada, Y.; Noma, A. Immunolocalization of lipoprotein(a) in wounded tissues. J. Histochem. Cytochem., 1997, 45, 559-568.

[61] Trieu, V.N.; Uckun, F.M. Apolipoprotein(a), a link between atherosclerosis and tumor angiogenesis. Biochem. Biophys. Res. Commun., 1999, 257, 714-718.

[62] Schulter, V.; Koolwijk, P.; Peters, E.; Frank, S.; Hrzenjak, A.; Graier, W.F.; van Hinsbergh, V.W.M.; Kostner, G.M. Impact of Apolipoprotein(a) on in vitro angiogenesis. Arterioscler. Thromb. Vasc. Biol., 2001, 21, 433-438.

[63] Kim, J.S.; Chang, J.H.; Yu, H.K.; Ahn, J.H.; Yum, J.S.; Lee, S.K.; Jung, K.H.; Park, D.H.; Yoon, Y.; Byun, S.M.; Chung, S.I. Inhibition of angiogenesis and angiogenesis-dependent tumor growth by the cryptic kringle fragments of human apolipoprotein(a). J. Biol. Chem., 2003, 278, 29000-29008.

[64] Harpel, P.C.; Hermann, A.; Zhang, X.; Ostfeld, I.; Borth, W. Lipoprotein(a), plasmin modulation, and atherogenesis. Thromb. Haemost., 1995, 74, 382-386.

[65] Harpel, P.C.; Gordon, B.R.; Parker, T.S. Plasmin catalyzes binding of lipoprotein (a) to immobilized fibrinogen and fibrin. Proc. Natl. Acad. Sci. USA, 1989, 86, 3847-3851.

[66] Loscalzo, J.; Weinfeld, M.; Fless, G.M.; Scanu, A.M. Lipoprotein(a), fibrin binding, and plasminogen activation. Arteriosclerosis, 1990, 10, 240-245.

[67] Harpel, P.C.; Chang, V.T.; Borth, W. Homocysteine and other sulfhydryl compounds enhance the binding of lipoprotein(a) to fibrin: A potential biochemical link between thrombosis, atherogenesis, and sulfhydryl compound metabolism. Proc. Natl. Acad. Sci. USA, 1992, 89, 10193-10197.

[68] Nachman R.L. Thrombosis and atherogenesis: Molecular connections. Blood, 1992, 79, 1897-1906.

[69] Fleury, V.; Lijnen, H.R.; Angles-Cano, E. Mechanism of the enhanced intrinsic activity of single-chain urokinase-type plasminogen activator during ongoing fibrinolysis. J. Biol. Chem., 1993, 268, 18554-18559.

[70] Harpel, P.C.; Chang, T.S.; Verderber, E. Tissue plasminogen activator and urokinase mediate the binding of Glu-plasminogen to plasma fibrin I. Evidence for new binding sites in plasmindegraded fibrin I. J. Biol. Chem., 1985, 260, 4432-4440.

[71] Hoylaerts, M.; Rijken, D.C.; Lijnen, H.R.; Collen, D. Kinetics of the activation of plasminogen by human tissue plasminogen activator. Role of fibrin. J. Biol. Chem., 1982, 257, 2912-2919.

[72] Lijnen, H.R.; Bachmann, F.; Collen, D.; Ellis, V.; Pannekoek, H.; Rijken, D.C.; Thorsen, S. Mechanism of plasminogen activation. $J$. Intern. Med., 1994, 236, 415-424.

[73] Suenson, E.; Lutzen, O.; Thorsen, S. Initial plasmin-degradation of fibrin as the basis of a positive feed-back mechanism in fibrinolysis. Eur. J. Biochem. 1984, 140, 513-522.

[74] Vali, Z.; Patthy, L. Location of the intermediate and high affinity $\omega$-aminocarboxylic acid-binding sites in human plasminogen. $J$ Biol. Chem., 1982, 257, 2104-2110.

[75] Hajjar, K.A.; Gavish, D.; Breslow, J.L.; Nachman, R.L. Lipoprotein(a) modulation of endothelial cell surface fibrinolysis and its potential role in atherosclerosis. Nature, 1989, 339, 303-305.

[76] Miles, L.A.; Fless, G.M.; Levin, E.G.; Scanu, A.M.; Plow, E.F. A potential basis for the thrombotic risks associated with lipoprotein(a). Nature, 1989, 339, 301-303.

[77] Rouy, D.; Grailhe, P.; Nigon, F.; Chapman, J.; Angles-Cano E. Lipoprotein(a) impairs generation of plasmin by fibrin-bound tissue-type plasminogen activator. In vitro studies in a plasma milieu. Arterioscler. Thromb., 1991, 11, 629-638.

[78] Buechler, C.; Ullrich, H.; Ritter, M.; Porsch-Oezcueruemez, M.; Lackner, K.J.; Barlage, S.; Friedrich, S.O.; Kostner, G.M.; Schmitz, G. Lipoprotein (a) up-regulates the expression of the plasminogen activator inhibitor 2 in human blood monocytes. Blood, 2001, 97 981-986.

[79] Fujisawa, M.; Haramaki, R.; Miyazaki, H.; Imaizumi, T.; Okuda, S. Role of lipoprotein (a) and TGF- $\beta 1$ in atherosclerosis of hemodialysis patients. J. Am. Soc. Nephrol., 2000, 11, 1889-1895.

[80] Bajaj, M.; Kuppuswamy, M.; Saito, H.; Spitzer, S.G.; Bajaj, S.P. Cultured normal human hepatocytes do not synthesize lipoproteinassociated coagulation inhibitor: Evidence that endothelium is the principal site of its synthesis. Proc. Natl. Acad. Sci. USA, 1990, 87, 8869-8873.

[81] Broze, G.; Warren, L; Novotny, W.F.; Higuchi, D.A.; Girard, J.J.; Miletich, J.P. The lipoprotein-associated coagulation inhibitor that inhibits the factor VII-tissue factor complex also inhibits factor Xa: Insight into its possible mechanism of action. Blood, 1988, 71, 335343.

[82] Lindhout, T.; Blezer, R.; Schoen, P.; Nordfang, O.; Reutelingsperger, C.; Hemker, H.C. Activation of factor X and its regulation by tissue factor pathway inhibitor in small-diameter capillaries lined with human endothelial cells. Blood, 1992, 79, 2909-2916.

[83] van der Logt, C.P.; Dirven, R.J.; Reitsma, P.H.; Bertina, R.M Expression of tissue factor and tissue factor pathway inhibitor in monocytes in response to bacterial lipopolysaccharide and phorbolester. Blood Coagul. Fibrinolysis, 1994, 5, 211-220.

[84] Werling, R.W.; Zacharski, L.R.; Kisiel, W.; Bajaj, S.P.; Memoli, V.A.; Rousseau, S.M. Distribution of tissue factor pathway inhibitor in normal and malignant human tissues. Thromb. Haemost., 1993, 69, 366-369

[85] Caplice, N.M.; Panetta, C.; Peterson, T.E.; Kleppe, L.S.; Mueske, C.S.; Kostner, G.M.; Broze, G.J.; Simari, R.D. Lipoprotein (a) binds and inactivates tissue factor pathway inhibitor: A novel link between lipoproteins and thrombosis. Blood, 2001, 98, 2980-2987.

[86] Blencowe, C.; Hermetter, A.; Kostner, G.M.; Deigner, H.P. Enhanced association of platelet-activating factor acetylhydrolase with lipoprotein (a) in comparison with low density lipoprotein. $J$. Biol. Chem., 1995, 270, 31151-31157.

[87] Tsironis, L.D.; Katsouras, C.S.; Lourida, E.S.; Mitsios, J.V.; Goudevenos, J.; Elisaf, M.; Tselepis, A.D. Reduced PAFacetylhydrolase activity associated with $\mathrm{Lp}(\mathrm{a})$ in patients with coronary artery disease. Atherosclerosis, 2004, 177, 193-201.

[88] Tsironis, L.D.; Mitsios, J.V.; Milionis, H.J.; Elisaf, M.; Tselepis, A.D. Effect of lipoprotein (a) on platelet activation induced by platelet-activating factor: Role of apolipoprotein (a) and endogenous PAF-acetylhydrolase. Cardiovasc. Res., 2004, 63, 130-138.

[89] Gries, A.; Gries, M.; Wurm, H.; Kenner, T.; Ijsseldijk, M.; Sixma, J.J.; Kostner, G.M. Lipoprotein(a) inhibits collagen-induced aggregation of thrombocytes. Arterioscler. Thromb. Vasc. Biol., 1996, 16, 648-655

[90] Dahl, T.; Kontny, F.; Slagsvold, C.E.; Christophersen, B.; Abildgaard, U.; Odegaard, O.R.; Morkrid, L.; Dale, J. Lipoprotein(a), 
other lipoproteins and hemostatic profiles in patients with ischemic stroke: The relation to cardiogenic embolism. Cerebrovasc. Dis., 2000, 10, 110-117.

[91] von Depka, M.; Nowak-Göttl, U.; Eisert, R.; Dieterich, C.; Barthels, M.; Scharrer, I.; Ganser, A.; Ehrenforth, S. Increased lipoprotein (a) levels as an independent risk factor for venous thromboembolism. Blood, 2000, 96, 3364-3368.

[92] Heller, C.; Heinecke, A.; Junker, R.; Knöfler, R.; Kosch, A.; Kurnik, K.; Schobess, R.; von Eckardstein, A.; Sträter, R.; Zieger, B.; Nowak-Göttl, U.; the Childhood Stroke Study Group. Cerebral venous thrombosis in children. A multifactorial origin. Circulation, 2003, 108, 1362-1367.

[93] Nowak-Göttl, U.; Junker, R.; Hartmeier, M.; Koch, H.G.; Münchow, N.; Assmann, G., von Eckardstein, A. Increased lipoprotein(a) is an important risk factor for venous thromboembolism in childhood. Circulation, 1999, 100, 743-748.

[94] Nowak-Göttl, U.; Sträter, R.; Heinecke, A.; Junker, R.; Koch, H.G.; Schuierer, G.; von Eckardstein, A; for the Childhood Stroke Study Group. Lipoprotein (a) and genetic polymorphisms of clotting factor $\mathrm{V}$, prothrombin, and methylenetetrahydrofolate reductase are risk factors of spontaneous ischemic stroke in childhood. Blood, 1999, 94, 3678-3682.

[95] Shindo, J.; Ishibashi, T.; Kijima, M.; Nakazato, K; Nagata, K.; Yokoyama, K.; Hirosaka, A.; Sato, E.; Kunii, H.; Yamaguchi, N.; Watanabe, N.; Saito, T.; Maehara, K.; Maruyama, Y. Increased plasminogen activator inhibitor-1 and apolipoprotein (a) in coronary atherectomy specimens in acute coronary syndromes. Coron. Artery Dis., 2001, 12, 573-579.

[96] Sträter, R.; Becker, S.; von Eckardstein, A.; Heinecke, A.; Gutsche, S.; Junker, R.; Kurnik, K.; Schobess, R.; Nowak-Göttl, U. Prospective assessment of risk factors for recurrent stroke during childhood - a 5-year follow-up study. Lancet, 2002, 360, 1540-1545.

[97] Franceschini, G.; Cofrancesco, E.; Safa, O.; Boschetti, C.; Tremoli, E.; Mussoni, L.; Sirtori, C.R.; Cortellaro, M. Association of lipoprotein(a) with atherothrombotic events and fibrinolytic variables. A case-control study. Thromb. Res., 1995, 78, 227-238.

[98] Lippi, G.; Bassi, A.; Brocco, G.; Manzato, F.; Marini, M.; Guidi, G. Lipoprotein(a) concentration is not associated with venous thromboembolism in a case control study. Haematologica, 1999, 84, 726-729.

[99] März, W.; Trommlitz, M.; Scharrer, I.; Gross, W. Apolipoprotein (a) concentrations are not related to the risk of venous thrombosis. Blood Coagul. Fibrinolysis, 1991, 2, 595-599.

[100] Asanuma, Y.; Kawai, S.; Aoshima, H.; Kaburaki, I.; Mizushima, Y. Serum lipoprotein(a) and apolipoprotein(a) phenotypes in patients with rheumatoid arthritis. Arthritis Rheum., 1999, 42, 443-447.

[101] Atsumi, T.; Khamashta, M.A.; Andujar, C.; Leandro, M.J.; Amengual, O.; Ames, P.R.; Hughes, G.R. Elevated plasma lipoprotein(a) level and its association with impaired fibrinolysis in patients with antiphospholipid syndrome. J. Rheumatol., 1998, 25, 69-73.

[102] Borba, E.F.; Santos, R.D.; Bonfa, E.; Vinagre, C.G.; Pileggi, F.J.; Cossermelli, W.; Maranhao, R.C. Lipoprotein(a) levels in systemic lupus erythematosus. J. Rheumatol., 1994, 21, 220-223.

[103] Cerinic, M.M.; Valentini, G.; Sorano, G.G.; d’Angelo, S.; Cuomo, G.; Fenu, L.; Generini, S.; Cinotti, S.; Morfini, M.; Pignone, A.; Guiducci, S.; del Rossok, A.; Kalfin, R.; Das, D.; Marongiu, F. Blood coagulation, fibrinolysis, and markers of endothelial dysfunction in systemic sclerosis. Semin. Arthritis Rheum., 2003, 32, 285-295.

[104] Dieplinger, H.; Lackner, C.; Kronenberg, F.; Sandholzer, C; Lhotta, K.; Hoppichler, F.; Graf, H.; König P. Elevated plasma concentrations of lipoprotein(a) in patients with end-stage renal disease are not related to the size polymorphism of apolipoprotein(a). J. Clin. Invest., 1993, 91, 397-401.

[105] Hirata, K.; Kikuchi, S.; Saku, K.; Jimi, S.; Zhang, B.; Naito, S.; Hamaguchi, H.; Arakawa, K. Apolipoprotein(a) phenotypes and serum lipoprotein(a) levels in maintenance hemodialysis patients with/without diabetes mellitus. Kidney Int., 1993, 44, 1062-1070.

[106] Ignatescu, M.; Kostner, K.; Zorn, G.; Kneussl, M.; Maurer, G.; Lang, I.M.; Huber, K. Plasma Lp(a) levels are increased in patients with chronic thromboembolic pulmonary hypertension. Thromb. Haemost., 1998, 80, 231-232.

[107] Kronenberg, F.; Konig, P.; Neyer, U.; Auinger, M.; Pribasnig, A.; Lang, U.; Reitinger, J.; Pinter, G.; Utermann, G.; Dieplinger, H. Multicenter study of lipoprotein(a) and apolipoprotein(a) phenotypes in patients with end-stage renal disease treated by hemodialy- sis or continuous ambulatory peritoneal dialysis. J. Am. Soc. Nephrol., 1995, 6, 110-120.

[108] Sechi, L.A.; Zingaro, L.; De Carli, S.; Sechi, G.; Catena, C.; Falleti, E.; Dell'Anna, E.; Bartoli, E. Increased serum lipoprotein(a) levels in patients with early renal failure. Ann. Intern. Med., 1998, 129, 457-461.

[109] Soulat, T.; Loyau, S.; Baudouin, V.; Maisonneuve, L.; HurtaudRoux, M.F.; Schlegel, N.; Loirat, C.; Angles-Cano, E. Effect of individual plasma lipoprotein(a) variations in vivo on its competition with plasminogen for fibrin and cell binding: An in vitro study using plasma from children with idiopathic nephrotic syndrome. Arterioscler. Thromb. Vasc. Biol., 2000, 20, 575-584.

[110] Fan, J.; Sun, H.; Unoki, H.; Shiomi, M.; Watanabe, T. Enhanced atherosclerosis in Lp(a) WHHL transgenic rabbits. Ann. N.Y. Acad. Sci., 2001, 947, 362-365

[111] Ichikawa, T.; Unoki, H.; Sun, H.; Shimoyamada, H.; Marcovina, S.; Shikama, H.; Watanabe, T.; Fan, J. Lipoprotein(a) promotes smooth muscle cell proliferation and dedifferentiation in atherosclerotic lesions of human apo(a) transgenic rabbits. Am. J. Pathol., 2002, 160, 227-236.

[112] Sun, H.; Unoki, H.; Wang, X.; Liang, J.; Ichikawa, T.; Arai, Y.; Shiomi, M.; Marcovina, S.M.; Watanabe, T.; Fan, J. Lipoprotein(a) enhances advanced atherosclerosis and vascular calcification in WHHL transgenic rabbits expressing human apolipoprotein(a). $J$. Biol. Chem., 2002, 277, 47486-47492.

[113] Bihari-Varga, M.; Gruber, E.; Rotheneder, M.; Zechner, R.; Kostner, G.M. Interaction of lipoprotein Lp(a) and low density lipoprotein with glycosaminoglycans from human aorta. Arteriosclerosis, 1988, 8, 851-857.

[114] D’Angelo, A.; Geroldi, D.; Hancock, M.A.; Valtulina, V.; Cornaglia, A.I.; Spencer, C.A.; Emanuele, E.; Calligaro, A.; Koschinsky, M.L.; Speziale, P.; Visai. L. The apolipoprotein(a) component of lipoprotein(a) mediates binding to laminin: Contribution to selective retention of lipoprotein(a) in atherosclerotic lesions. Biochim. Biophys. Acta, 2005, 1687, 1-10.

[115] Dahlen, G.; Ericson, C.; Berg, K. In vitro studies of the interaction of isolated $\mathrm{Lp}$ (a) lipoprotein and other serum lipoproteins with glycosaminoglycans. Clin. Genet., 1978, 14, 36-42.

[116] Poon, M.; Zhang, X.; Dunsky, K.G.; Taubman, M.B.; Harpel, P.C. Apolipoprotein(a) induces monocyte chemotactic activity in human vascular endothelial cells. Circulation, 1997, 96, 2514-2519.

[117] Sotiriou, S.N.; Orlova, V.V.; Al-Fakhri, N.; Ihanus, E.; Economopoulou, M.; Isermann, B.; Bdeir, K.; Nawroth, P.P.; Preissner, K.T.; Gahmberg, C.G.; Koschinsky, M.L.; Chavakis T. Lipoprotein(a) in atherosclerotic plaques recruits inflammatory cells through interaction with Mac-1 integrin. FASEB J., 2006, 20, 559561 .

[118] Grainger, D.J.; Kirschenlohr, H.L.; Metcalfe, J.C.; Weissberg, P.L.; Wade, D.P.; Lawn, R.M. Proliferation of human smooth muscle cells promoted by lipoprotein(a). Science, 1993, 260, 1655-1658.

[119] Ross, R. The pathogenesis of atherosclerosis: A perspective for the 1990s. Nature, 1993, 362, 801-809.

[120] Ross R. N. Atherosclerosis - an inflammatory disease. N. Engl. J. Med., 1999, 340, 115-126.

[121] Grainger, D.J.; Kemp, P.R.; Liu, A.C.; Lawn, R.M.; Metcalfe, J.C. Activation of transforming growth factor-beta is inhibited in transgenic apolipoprotein(a) mice. Nature, 1994, 370, 460-462.

[122] Kojima, S.; Harpel, P.C.; Rifkin, D.B. Lipoprotein (a) inhibits the generation of transforming growth factor beta: An endogenous inhibitor of smooth muscle cell migration. J. Cell Biol., 1991, 113, 1439-1445.

[123] Ridker, P.M.; Hennekens, C.A.; Stampfer, M.J. A prospective study of lipoprotein(a) and the risk of myocardial infarction. JAMA 1993, 270, 2195-2199.

[124] Min, W.K.; Lee, J.O.; Huh, J.W. Relation between lipoprotein(a) concentrations in patients with acute-phase response and risk analysis for coronary heart disease. Clin. Chem., 1997, 43, 18911895

[125] Yun, K.A.; Lee, W.; Min, W.K.; Chun, S.; Lee, Y.W.; Kim, S.B.; Park, J.S.; Yang, W.S.; Park, H.; Hwang, S.H. Discrepancy of interleukin-6 levels between end-stage renal disease patients and patients with acute-phase response with increased lipoprotein(a) concentrations. Scand. J. Clin. Lab. Invest., 2004, 64, 223-228.

[126] Pearce, E.N. Hypothyreoidism and dyslipidemia: Modern concepts and approaches. Curr. Cardiol. Rep., 2004, 6, 451-456. 
[127] Frazer, K.A.; Narla, G.; Zhang, J.L.; Rubin, E.M. The apolipoprotein(a) gene is regulated by sex hormones, and acute phase inducers in YAC transgenic mice. Nat. Genet., 1995, 9, 424-431.

[128] Marcovina, S.M.; Lippi, G.; Bagatell, C.J.; Bremner, W.J. Testosterone-induced suppression of lipoprotein(a) in normal men; relation to basal lipoprotein(A) level. Atherosclerosis, 1996, 122, 8995.

[129] Barnhart, K.T.; Freeman, E.; Grisso, J.A.; Rader, D.J.; Sammel, M.; Kapoor, S.; Nestler, J.E. The effect of dehydroepiandrosterone supplementation to symptomatic perimenopausal women on serum endocrine profiles, lipid parameters, and health related quality of life, J. Clin. Endocrinol. Metab., 1999, 84, 3896-3902.

[130] Berglund, L.; Carlstrom, K.; Stege, R.; Gottlieb, C.; Eriksson, M.; Angelin, B.; Henriksson, P. Hormonal regulation of serum lipoprotein(a) levels: Effects of parenteral administration of estrogen or testosterone in males. J. Clin. Endocrinol. Metab., 1996, 81, 26332637.

[131] Hartgens, F.; Rietjens, G.; Keizer, H.A.; Kuipers, H.; Wolffenbuttel, B.H.R. Effects of androgenic-anabolic steroids on apolipoproteins and lipoprotein(a). Br. J. Sports Med., 2004, 38, 253-259.

[132] Arrer, E.; Jungwirth, A.; Mack, D.; Frick, J.; Patsch, W. Treatment of prostate cancer with gonadotropin-releasing hormone analogue: Effect on lipoprotein(a). J. Clin. Endocrinol. Metab., 1996, 81, 2508-2511.

[133] Denti, L.; Pasolini, G.; Cortellini, P.; Ferretti, S.; Sanfelici, L.; Ablondi, F.; Valenti, G. Effects of androgen suppression by gonadotropin-releasing hormone agonist and flutamide on lipid metabolism in men with prostate cancer: Focus on lipoprotein(a). Clin. Chem., 1996, 42, 1176-1181.

[134] Hislop, M.S.; St Clair Gibson, A.; Lambert, M.I.; Noakes, T.D.; Marais, A.D. Effects of androgen manipulation on postprandial triglyceridemia, low-density lipoprotein particle size and lipoprotein(a) in men. Atherosclerosis, 2001, 159, 425-432.

[135] von Eckardstein, A.; Kliesch, S.; Nieschlag, E.; Chirazi, A.; Assmann, G.; Behre, H.M. Suppression of endogenous testosterone in young men increases serum levels of high density lipoprotein subclass lipoprotein A-I and lipoprotein(a). J. Clin. Endocrinol. Metab., 1997, 82, 3367-3372.

[136] Denti, L.; Pisolini, G.; Cortellini, P.; Sanfelici, L.; Benedetti, R.; Cecchetti, A.; Ferretti, S.; Bruschieri, L.; Abbondi, F.; Valenti, G. Changes in HDL-cholesterol and lipoprotein Lp(a) after 6-month treatment with finasteride in males affected by benign prostatic hyperplasia (BPH). Atherosclerosis, 2000, 152, 159-166.

[137] Hodgin, J.B.; Maeda, N. Minireview: Estrogen and mouse models of atherosclerosis. Endocrinology, 2002, 143, 4495-4501.

[138] Moskowitz D. A comprehensive review of the safety and efficacy of bioidentical hormones for the management of menopause and related health risks. Altern. Med. Rev., 2006, 11, 208-223.

[139] Elhadd, T.A.; Neary, R.; Abdu, T.A.; Kennedy, G.; Hill, A.; McLaren, M.; Akber, M.; Belch, J.J.; Clayton, R.N. Influence of the hormonal changes during the normal menstrual cycle in healthy young women on soluble adhesion molecules, plasma homocysteine, free radical markers and lipoprotein fractions. Int. Angiol., 2003, 22, 222-228

[140] Haines, C.J.; Cheung, L.P.; Lam, C.W. Changes in atherogenic lipids and lipoproteins during natural and hyperstimulated cycles in healthy women. Fertil. Steril., 1997, 68, 231-235.

[141] Reed, R.G.; Kris-Etherton, P.; Stewart, P.W.; Pearson, T.A.; for the DELTA (Dietary Effects on Lipoproteins and Thrombogenic Activity) Investigators. Variation of lipids and lipoproteins in premenopausal women compared with men and postmenopausal women. Metabolism, 2000, 49, 1101-1105.

[142] Ricci, G.; Tamaro, G.; Simeone, R.; Giolo, E.; Nucera, G.; de Seta, F.; Guaschino, S. Lipoprotein(a) changes during natural menstrual cycle and ovarian stimulation with recombinant and highly purified urinary FSH. Hum. Reprod., 2001, 16, 449-456.

[143] Bayrak, A.; Aldemir, D.A.; Bayrak, T.; Corakci, A.; Dursun, P. The effect of hormone replacement therapy on the levels of serum lipids, apolipoprotein AI, apolipoprotein B and lipoprotein (a) in Turkish postmenopausal women. Arch. Gynecol. Obstet., 2006, 274, 289-296.

[144] Bruschi, F.; Meschia, M.; Soma, M.; Perotti, D.; Paletti, R.; Crosignani, P.G. Lipoprotein(a) and other lipids after oophorectomy and estrogen replacement therapy. Obstet. Gynecol., 1996, $886,950-954$
[145] Kim, C.J.; Ryu, W.S.; Kwak, J.W.; Park, C.T.; Ryoo, U.H. Changes in $\mathrm{Lp}$ (a) lipoprotein and lipid levels after cessation of female sex hormone production and estrogen replacement therapy. Arch. Intern. Med., 1996, 156, 500-504.

[146] Saarto, T.; Blomqvist, C.; Ehnholm, C.; Taskinen, M.R.; Elomaa, I. Effects of chemotherapy-induced castration on serum lipids and apoproteins in premenopausal women with node-positive breast cancer. J. Clin. Endocrinol. Metab., 1996, 81, 4453-4457.

[147] Shlipak, M.G.; Simon, J.A.; Vittinghoff, E.; Lin, F.; BarrettConnor, E.; Knopp, R.H.; Levy, R.I.; Hulley, S.B. Estrogen and progestin, lipoprotein(a), and the risk of recurrent coronary heart disease events after menopause. JAMA, 2000, 283, 1845-1852.

[148] Ushioda, M.; Makita, K.; Takamatsu, K.; Horiguchi, F.; Aoki, D. Serum Lipoprotein(a) dynamics before/after menopause and longterm effects of hormone replacement therapy on lipoprotein(a) levels in middle-aged and older Japanese women. Horm. Metab. Res., 2006, 38, 581-586.

[149] Kusama, M.; Miyauchi, K.; Aoyama, H.; Sano, M.; Kimura, M.; Mitsuyama, S.; Komaki, K.; Doihara, H. Effects of toremifene (TOR) and tamoxifen (TAM) on serum lipids in postmenopausal patients with breast cancer. Breast Cancer Res. Treat., 2004, 88, 18.

[150] Liberopoulos, E.; Karabina, S.A.; Tselepis, A.; Bairaktari, E.; Nicolaides, C.; Pavlidis, N.; Elisaf, M. Are the effects of tamoxifen on the serum lipid profile modified by apolipoprotein E phenotypes? Oncology, 2002; 62, 115-120.

[151] Wasan, K.M.; Goss, P.E.; Pritchard, P.H.; Shepherd, L.; Palmer, M.J.; Liu, S.; Tu, D., Ingle, J.N.; Heath, M.; Deangelis, D.; Perez, E.A. The influence of letrozole on serum lipid concentrations in postmenopausal women with primary breast cancer who have completed 5 years of adjuvant tamoxifen (NCIC CTG MA.17L). Ann. Oncol., 2005, 16, 707-715.

[152] Arnadottir, M.; Berg, A.L.; Dallongeville, J.; Fruchart, J.C.; Nilsson-Ehle, P. Adrenocorticotrophic hormone lowers serum Lp(a) and LDL cholesterol concentrations in hemodialysis patients. Kidney Int., 1997, 52, 1651-1655.

[153] Arnadottir, M.; Berg, A.L.; Kronenberg, F.; Lingenhel, A.; Hugosson, T.; Hegbrant, J.; Nilsson-Ehle, P. Corticotropin-induced reduction of plasma lipoprotein(a) concentrations in healthy individuals and hemodialysis patients: Relation to apolipoprotein(a) size polymorphism. Metabolism, 1999, 48, 342-346.

[154] Berg, A.L.; Rafnsson, A.T.; Johannsson, M.; Dallongeville, J.; Arnadottir, M. The effects of adrenocorticotrophic hormone and an equivalent dose of cortisol on the serum concentrations of lipids, lipoproteins, and apolipoproteins. Metabolism, 2006, 55, 10831087.

[155] Clodi, M.; Oberbauer, R.; Waldhäusl, W.; Maurer, G.; Kostner, G.M.; Kostner, K. Urinary excretion of apo(a) fragments in NIDDM patients. Diabetologia, 1997, 40, 1455-1460

[156] Catena, C.; Novello, M.; Dotto, L.; De Marchi, S.; Sechi, L.A. Serum lipoprotein(a) concentrations and alcohol consumption in hypertension: Possible relevance for cardiovascular damage. $J$. Hypertens., 2003, 21, 281-288.

[157] Fontana, P.; Mooser, V.; Bovet, P.; Shamlaye, C.; Burnand, B.; Lenain, V.; Marcovina, S.M.; Riesen, W., Darioli, R. Dosedependent inverse relationship between alcohol consumption and serum Lp(a) levels in black African males. Arterioscler. Thromb. Vasc. Biol., 1999, 19, 1060-1065.

[158] Delarue, J.; Husson, M.; Schellenberg, F.; Tichet, J.; Vol, S.; Couet, C.; Lamisse, F. Serum lipoprotein(a) [Lp(a)] in alcoholic men: Effect of withdrawal. Alcohol, 1996, 13, 309-314.

[159] Paassilta, M.; Kervinen, K.; Linnaluoto, M.; Kesaniemi, Y.A. Alcohol withdrawal-induced change in lipoprotein(a): Association with the growth hormone/insulin-like growth factor-I (IGF-I)/IGFbinding protein-1 (IGFBP-1) axis. Arterioscler. Thromb. Vasc. Biol., 1998, 18, 650-654.

[160] Rakic, V.; Puddey, I.B.; Dimmitt, S.B.; Burke, V.; Beilin, L.J. A controlled trial of the effects of alcohol intake on serum lipid levels in regular drinkers. Atherosclerosis, 1998, 137, 243-252.

[161] Katan, M.B.; Zock, P.L.; Mensink, R.P. Trans fatty acids and their effects on lipoproteins in humans. Annu. Rev. Nutr., 1995, 15, 473493.

[162] Sundram, K.; Ismail, A.; Hayes, K.C.; Jeyamalar, R.; Pathmanathan, R. Trans (elaidic) fatty acids adversely affect the lipoprotein profile relative to specific saturated fatty acids in humans. J. Nutr., 1997, 127, 514S-520S. 
[163] Marcovina, S.M.; Kennedy, H.; Bittolo Bon, G.; Cazzolato, G.; Galli, C.; Casiglia, E.; Puato, M.; Pauletto, P. Fish intake, independent of apo(a) size, accounts for lower plasma lipoprotein(a) levels in Bantu fishermen of Tanzania: The Lugalawa Study. Arterioscler. Thromb. Vasc. Biol., 1999, 19, 1250-1256.

[164] Pedersen, J.I.; Muller, H.; Seljeflot, I.; Kirkhus, B. Palm oil versus hydrogenated soybean oil: Effects on serum lipids and plasma haemostatic variables. Asia Pac. J. Clin. Nutr., 2005, 14, 348-357.

[165] Shinozaki, K.; Kambayashi, J.; Kawasaki, T.; Uemura, Y.; Sakon, M.; Shiba, E.; Shibuya, T.; Nakamura, T.; Mori, T. The long-term effect of eicosapentaenoic acid on serum levels of lipoprotein (a) and lipids in patients with vascular disease. J. Atheroscler. Thromb., 1996, 2, 107-109.

[166] Rodrioguez Reguero, J.J.; Iglesias Cubero, G.; Martinez Celada, M.; Fueyo, J.R.; Sanchez Posada, I.; Braga, S.; Cortina, A. Interrelationships between lipoprotein(a) and other cardiovascular risk factors. Cardiology, 1995, 86, 432-435.

[167] Os, I.; Hoieggen, A.; Larsen, A.; Sandset, P.M.; Djurovic, S.; Berg, K.; Os, A.; Birkeland, K.; Westheim, A. Smoking and relation to other risk factors in postmenopausal women with coronary artery disease, with particular reference to whole blood viscosity and beta-cell function. J. Intern. Med., 2003, 253, 232-239.

[168] Siekmeier, R.; März, W.; Kronenberger, H.; Seiffert, U.B.; Groß, W. Effects of cigarette smoking on plasma lipids, apolipoproteins, and lipoprotein (a). Clin. Chem., 1994, 40, 1350-1351.

[169] Ashavaid, T.F.; Kondkar, A.A.; Todur, S.P.; Dherai, A.J.; Morey, J.; Raghavan, R. Lipid, lipoprotein, apolipoprotein and lipoprotein(a) levels: Reference intervals in a healthy Indian population. $J$. Atheroscler. Thromb., 2005, 12, 251-259.

[170] Selby, J.V.; Austin, M.A.; Sandholzer, C.; Quesenberry, C.P.; Zhang, D.; Mayer, E.; Utermann, G. Environmental and behavioral influences on plasma lipoprotein(a) concentration in women twins. Prev. Med., 1994, 23, 345-353.

[171] Tello-Montoliu, A.; Roldan, V.; Climent, V.E.; Sogorb, F.; Lip, G.Y.H.; Marín, F. Does smoking status influence the effect of physical exercise on fibrinolytic function in healthy volunteers? $J$. Thromb. Thrombolysis., 2006, 21, 163-166.

[172] Buyukyazi, G. Differences in blood lipids and apolipoproteins between master athletes, recreational athletes and sedentary men. $J$. Sports Med. Phys. Fitness, 2005, 45, 112-120.

[173] Byrne, D.J.; Jagroop, I.A.; Montgomery, H.E.; Thomas, M.; Mikhailidis, D.P.; Milton, N.G.; Winder, A.F. Lipoprotein (a) does not participate in the early acute phase response to training or extreme physical activity and is unlikely to enhance any associated immediate cardiovascular risk. J. Clin. Pathol., 2002, 55, 280-285.

[174] Kishali, N.F.; Imamoglu, O.; Kaldirimci, M.; Akyol, P.; Yildirim, $\mathrm{K}$. Comparison of lipid and lipoprotein values in men and women differing in training status. Int. J. Neurosci., 2005, 115, 1247-1257.

[175] Cardoso, G.C.; Posadas, C.; Orvananos, O.O.; Peniche, C.; Zamora, J.; Aguilar, R.; Holguin, J.A.; Raynaud, A.S.; Morrisett, J.D.; Guevara, J. Long distance runners and body-builders exhibit elevated plasma levels of lipoprotein(a). Chem. Phys. Lipids, 1994, 67-68, 207-221.

[176] Batiste, M.C.; Schaefer, E.J. Diagnosis and management of lipoprotein abnormalities. Nutr. Clin. Care, 2002, 5, 115-123.

[177] Birjmohun, R.S.; Hutten, B.A.; Kastelein, J.J.P.; Stroes, E.S.G. Increasing HDL cholesterol with extended-release nicotinic acid: From promise to practice. Neth. J. Med., 2004, 62, 229-234.

[178] McCormack, P.L.; Keating, G.M. Prolonged-release nicotinic acid. A review of its use in the treatment of dyslipidemia. Drugs, 2005, 65, 2719-2740.

[179] McKenney, J. New perspectives on the use of niacin in the treatment of lipid disorders. Arch. Intern. Med., 2004, 164, 697-705.

[180] Ramharack, R.; Spahr, M.A.; Hicks, G.W.; Kieft, K.A.; Brammer, D.W.; Minton, L.L.; Newton, R.S. Gemfibrozil significantly lowers cynomolgus monkey plasma lipoprotein[a]-protein and liver apolipoprotein[a] mRNA levels. J. Lipid Res., 1995, 36, 1294-1304.

[181] Bambauer, R. Is lipoprotein (a)-apheresis useful? Ther. Apher. Dial., 2005, 9, 142-147.

[182] Bosch, T.; Gahr, S.; Belschner, U.; Schaefer, C.; Lennertz, A.; Rammo, J.; for the DALI Study Group. Direct adsorption of lowdensity lipoprotein by DALI-LDL-apheresis: Results of a prospective long-term multicenter follow-up covering 12,291 sessions. Ther. Apher. Dial., 2006, 10, 210-218.

[183] Schuff-Werner, P.; Gohlke, H.; Bartmann, U.; Baggio, G.; Corti, M.C.; Dinsenbacher, A.; Eisenhauer, T.; Grützmacher, P.; Keller,
C.; Kettner, U.; Kleophas, W.; Köster, W.; Olbricht, C.J.; Richter, W.O.; Seidel, D.; The HELP-Study Group. The HELP-LDLapheresis multicentre study, an angiographically assessed trial on the role of LDL-apheresis in the secondary prevention of coronary heart disease. II. Final evaluation of the effect of regular treatment on LDL-cholesterol plasma concentrations and the course of coronary heart disease. The HELP-Study Group. Heparin-induced extra-corporeal LDL-precipitation. Eur. J. Clin. Invest., 1994, 24, 724-732.

[184] Dobs, A.S.; Prasad, M.; Goldberg, A.; Guccione, M.; Hoover, D.R. Changes in serum lipoprotein(a) in hyperlipidemic subjects undergoing long-term treatment with lipid-lowering drugs. Cardiovasc. Drugs Ther., 1995, 9, 677-684.

[185] Kostner, G.M.; Gavish, D.; Leopold, B.; Bolzano, K.; Weintraub, M.S.; Breslow, J.L. HMG CoA reductase inhibitors lower LDL cholesterol without reducing Lp(a) levels. Circulation, 1989, 80, 1313-1319.

[186] Leren, T.P.; Hjermann, I.; Foss, O.P.; Leren, P.; Berg, K. Longterm effect of lovastatin alone and in combination with cholestyramine on lipoprotein (a) level in familial hypercholesterolemic subjects. Clin. Investig., 1992, 70, 711-718.

[187] van Wissen, S.; Smilde, T.J.; Trip, M.D.; de Boo, T.; Kastelein, J.J.P.; Stalenhoef, A.F.H. Long term statin treatment reduces lipoprotein(a) concentrations in heterozygous familial hypercholesterolaemia. Heart, 2003, 89, 893-896.

[188] Wu, S.C.; Shiang, J.C.; Lin, S.L.; Wu, T.L.; Huang, W.C.; Chiou, K.R.; Liu, C.P. Efficacy and safety of statins in hypercholesterolemia with emphasis on lipoproteins. Heart Vessels, 2005, 20, 217-223.

[189] Bays, H.; Stein, E.A. Pharmacotherapy for dyslipidaemia - current therapies and future agents. Expert Opin. Pharmacother., 2003, 4 , 1901-1938.

[190] Derosa, G.; Cicero, A.F.; d’Angelo, A.; Gaddi, A.; Ciccarelli, L.; Piccinni, M.N., Salvadeo, S.A.; Pericolo, F.; Ferrari, I.; Gravina, A.; Ragonesi, P.D. Effects of 1 year of treatment with pioglitazone or rosiglitazone added to glimepiride on lipoprotein (a) and homocysteine concentrations in patients with type 2 diabetes mellitus and metabolic syndrome: A multicenter, randomized, double-blind, controlled clinical trial. Clin. Ther., 2006, 28, 679-688.

[191] Sarafidis, P.A.; Lasaridis, A.N.; Nilsson, P.M.; Mouslech, T.F.; Hitoglou-Makedou, A.D.; Stafylas, P.C.; Kazakos, K.A.; Yovos J.G.; Tourkantonis, A.A. The effect of rosiglitazone on novel atherosclerotic risk factors in patients with type 2 diabetes mellitus and hypertension. An open-label observational study. Metabolism, 2005, 54, 1236-1242.

[192] Grekas, D.; Kassimatis, E.; Makedou, A.; Bacharaki, D.; Bamichas, G.; Tourkantonis, A. Combined treatment with low-dose pravastatin and fish oil in post-renal transplantation dislipidemia. Nephron, 2001, 88, 329-333.

[193] Derosa, G.; Cicero, A.F.; Gaddi, A.; Mugellini, A.; Ciccarelli, L. Fogari, R. The effect of L-carnitine on plasma lipoprotein(a) levels in hypercholesterolemic patients with type 2 diabetes mellitus. Clin. Ther., 2003, 25, 1429-1439.

[194] Rahbar, A.R.; Shakerhosseini, R.; Saadat, N.; Taleban, F.; Pordal, A.; Gollestan, B. Effect of L-carnitine on plasma glycemic and lipidemic profile in patients with type II diabetes mellitus. Eur. $J$. Clin. Nutr., 2005, 59, 592-596.

[195] Sirtori, C.R.; Calabresi, L.; Ferrara, S.; Pazzucconi, F.; Bondioli, A.; Baldassarre, D.; Birreci, A.; Koverech, A. L-carnitine reduces lipoprotein(a) levels in patients with hyper Lp(a). Nutr. Metab. Cardiovasc. Dis., 2000, 10, 247-251.

[196] Solfrizzi, V.; Capurso, C.; Colacicco, A.M.; d’Introno, A.; Fontana, C.; Capurso, S.A.; Torres, F.; Gadaleta, A.M.; Koverech, A.; Capurso, A.; Panza, F. Efficacy and tolerability of combined treatment with L-carnitine and simvastatin in lowering lipoprotein(a) serum levels in patients with type 2 diabetes mellitus. Atherosclerosis, 2006, 188, 455-461.

[197] Cicero, A.F.; Derosa, G.; Miconi, A.; Laghi, L.; Nascetti, S.; Gaddi, A. Treatment of massive hypertriglyceridemia resistant to PUFA and fibrates: A possible role for the coenzyme Q10? Biofactors, 2005, 23, 7-14.

[198] Cicero, A.F.; Derosa, G.; Miconi, A.; Laghi, L.; Nascetti, S.; Gaddi, A. Possible role of ubiquinone in the treatment of massive hypertriglyceridemia resistant to PUFA and fibrates. Biomed. Pharmacother., 2005, 59, 312-317. 
[199] Akaike, M.; Azuma, H.; Kagawa, A.; Matsumoto, K.; Hayashi, I.; Tamura, K.; Nishiuchi, T.; Iuchi, T.; Takamori, N.; Aihara, K.; Yoshida, T.; Kanagawa, Y.; Matsumoto, T. Effect of aspirin treatment on serum concentrations of lipoprotein(a) in patients with atherosclerotic diseases. Clin. Chem., 2002, 48, 1454-1459.

[200] Kagawa, A.; Azuma, H.; Akaike, M.; Kanagawa, Y.; Matsumoto, T. Aspirin reduces apolipoprotein(a) (apo(a)) production in human hepatocytes by suppression of apo(a) gene transcription. J. Biol. Chem., 1999, 274, 34111-34115.

[201] Rifai, N.; Ma, J.; Sacks, F.M.; Ridker, P.M.; Hernandez, W.J.; Stampfer, M.J.; Marcovina, S.M. Apolipoprotein(a) size and lipoprotein(a) concentration and future risk of angina pectoris with evidence of severe coronary atherosclerosis in men: The Physicians' Health Study. Clin. Chem., 2004, 50, 1364-1371.

[202] Scanu, A.M. Lipoprotein(a) and the atherothrombotic process: Mechanistic insights and clinical implications. Curr. Atheroscler. Rep., 2003, 5, 106-113.

[203] Bostom, A.G.; Gagnon, D.R.; Cupples, L.A.; Wilson, P.W.; Jenner, J.L.; Ordovas, J.M.; Schaefer, E.J.; Castelli, W.P. A prospective investigation of elevated lipoprotein (a) detected by electrophoresis and cardiovascular disease in women. The Framingham Heart Study. Circulation, 1994, 90, 1688-1695.

[204] Nguyen, T.T.; Ellefson, R.D.; Hodge, D.O.; Bailey, K.R.; Kottke, T.E.; Abu-Lebdeh, H.S. Predictive value of electrophoretically detected lipoprotein(a) for coronary heart disease and cerebrovascular disease in a community-based cohort of 9936 men and women. Circulation, 1997, 96, 1390-1397.
[205] Rodriguez, C.R.; Seman, L.J.; Ordovas, J.M.; Jenner, J.; Genest, M.S.; Wilson, P.W.; Schaefer, E.J. Lipoprotein(a) and coronary heart disease. Chem. Phys. Lipids, 1994, 67-68, 389-398.

[206] Dati, F.; Tate, J.R.; Marcovina, S.M.; Steinmetz, A.; on behalf of the IFCC Working Group for Lipoprotein(a) Assay Standardization. First WHO/IFCC International Reference Reagent for Lipoprotein(a) for Immunoassay - Lp(a) SRM 2B. Clin. Chem. Lab. Med., 2004, 42, 670-676.

[207] Marcovina, S.M.; Koschinsky, M.L.; Albers, J.J.; Skarlatos, S Report of the National Heart, Lung, and Blood Institute Workshop on lipoprotein(a) and cardiovascular disease: Recent advances and future directions. Clin. Chem., 2003, 49, 1785-1796.

[208] Craig, W.Y.; Poulin, S.E.; Forster, N.R.; Neveux, L.M.; Wald, N.J.; Ledue, T.B. Effect of sample storage on the assay of lipoprotein(a) by commercially available radial immunodiffusion and enzymelinked immunosorbent assay kits. Clin. Chem., 1992, 38, 550-553.

[209] Devanapalli, B.; Lee, S.; Mahajan, D.; Bermingham, M. Lipoprotein (a) in an immigrant Indian population sample in Australia. $\mathrm{Br}$. J. Biomed. Sci., 2002, 59, 119-122.

[210] Kronenberg, F.; Trenkwalder, E.; Dieplinger, H.; Utermann, G. Lipoprotein(a) in stored plasma samples and the ravages of time. Why epidemiological studies might fail. Arterioscler. Thromb. Vasc. Biol., 1996, 16, 1568-1572.

[211] NCEP III. Third Report of the National Cholesterol Education Program (NCEP) Adult Treatment Panel III: National Institute of Health; 2002 September 2002. Report No. 02-5215.

(C) Siekmeier et al.; Licensee Bentham Open.

This is an open access article licensed under the terms of the Creative Commons Attribution Non-Commercial License (http://creativecommons.org/licenses/ by-nc/3.0/) which permits unrestricted, non-commercial use, distribution and reproduction in any medium, provided the work is properly cited. 